\title{
Formation of secondary organic aerosol in the Paris pollution plume and its impact on surrounding regions
}

\author{
Q. J. Zhang ${ }^{1, a}$, M. Beekmann ${ }^{1}$, E. Freney ${ }^{2}$, K. Sellegri ${ }^{2}$, J. M. Pichon ${ }^{2}$, A. Schwarzenboeck ${ }^{2}$, A. Colomb ${ }^{2}$, \\ T. Bourrianne ${ }^{3}$, V. Michoud ${ }^{1, b}$, and A. Borbon ${ }^{1}$ \\ ${ }^{1}$ Laboratoire Interuniversitaire des Systèmes Atmosphériques (LISA/IPSL), UMR CNRS 7583, Université Paris Est Créteil \\ (UPEC) and Université Paris Diderot (UPD), Paris, France \\ ${ }^{2}$ Laboratoire de Météorologie Physique, Clermont-Ferrand, France \\ ${ }^{3}$ Centre National de Recherches Météorologiques, Météo-France, Toulouse, URA1357, France \\ anow at: Aria Technologies, Boulogne-Billancourt, France \\ bnow at: Mines Douai, SAGE, 59508 Douai, France \\ Correspondence to: Q. J. Zhang (qzhang@aria.fr)
}

Received: 19 January 2015 - Published in Atmos. Chem. Phys. Discuss.: 17 March 2015

Revised: 6 September 2015 - Accepted: 16 November 2015 - Published: 18 December 2015

\begin{abstract}
Secondary pollutants such as ozone, secondary inorganic aerosol, and secondary organic aerosol formed in the plumes of megacities can affect regional air quality. In the framework of the FP7/EU MEGAPOLI (Megacities: Emissions, urban, regional and Global Atmospheric POLlution and climate effects, and Integrated tools for assessment and mitigation) project, an intensive campaign was launched in the greater Paris region in July 2009. The major objective was to quantify different sources of organic aerosol (OA) within a megacity and in its plume. In this study, we use airborne measurements aboard the French ATR-42 aircraft to evaluate the regional chemistry-transport model CHIMERE within and downwind of the Paris region. Two mechanisms of secondary OA (SOA) formation are used, both including SOA formation from oxidation and chemical aging of primary semivolatile and intermediate volatility organic compounds (SI-SOA) in the volatility basis set (VBS) framework. As for SOA formed from traditional VOC (volatile organic compound) precursors (traditional SOA), one applies chemical aging in the VBS framework adopting different SOA yields for high- and low- $\mathrm{NO}_{x}$ environments, while another applies a single-step oxidation scheme without chemical aging. Two emission inventories are used for discussion of emission uncertainties. The slopes of the airborne OA levels versus $\mathrm{O}_{x}$ (i.e., $\mathrm{O}_{3}+\mathrm{NO}_{2}$ ) show $\mathrm{SOA}$ formation normalized with respect to photochemical activity and are used for specific evaluation of the OA scheme in the model. The simu-
\end{abstract}

lated slopes were overestimated slightly by factors of $1.1,1.7$ and 1.3 with respect to those observed for the three airborne measurements, when the most realistic "high- $\mathrm{NO}_{x}$ " yields for traditional SOA formation in the VBS scheme are used in the model. In addition, these slopes are relatively stable from one day to another, which suggests that they are characteristic for the given megacity plume environment. The configuration with increased primary organic aerosol (POA) emissions and with a single-step oxidation scheme of traditional SOA also agrees with the $\mathrm{OA} / \mathrm{O}_{x}$ slopes (about $\pm 50 \%$ with respect to the observed ones); however, it underestimates the background. Both configurations are coherent with observed OA plume buildup, but they show very different SI-SOA and traditional anthropogenic SOA (ASOA) contributions. It is hence concluded that available theoretical knowledge and available data in this study are not sufficient to discern the relative contributions of different types of anthropogenic SOA in the Paris pollution plume, while its sum is correctly simulated. Based on these simulations, for specific plumes, the anthropogenic OA buildup can reach between 8 and $10 \mu \mathrm{g} \mathrm{m}^{-3}$. For the average of the month of July 2009, maximum OA increases due to emissions from the Paris agglomeration are noticed close to the agglomeration at various length scales: several tens (for primary OA) to hundreds (for SI-SOA and ASOA) of kilometers from the Paris agglomeration. In addition, BSOA (SOA formed from biogenic VOC precursors) 


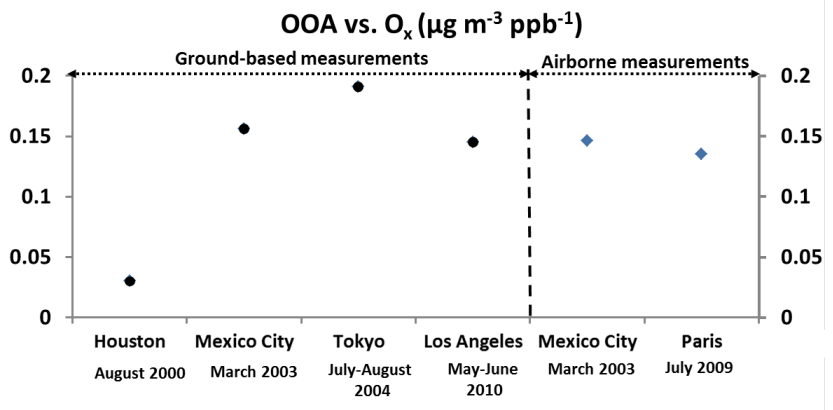

Figure 1. Ratios of OOA vs. $\mathrm{O}_{x}$ from studies in Mexico City, Houston, Los Angeles, Tokyo and Paris. Ratios for Houston, Los Angeles and Tokyo are derived from ground-based measurements during typically 1 month and located in the metropolitan area. For Houston, the ratio derived during influences from a combination of urban and petrochemical emissions, typically $0.03 \mu \mathrm{g} \mathrm{m}^{-3} \mathrm{ppb}^{-1}$ (Wood et al., 2010), is presented. Ratios for Paris and Mexico City are derived from three and two individual flights, respectively, performed at about 100-150 km downwind from the agglomeration.

is an important contributor to regional OA levels (inside and outside the Paris plume).

\section{Introduction}

The number of large agglomerations ("megacities") is increasing due to population clustering in urban regions (UN, 2014). Human activities in the megacities cause important negative effects on air quality (Gurjar et al., 2010). Pollutants like ozone and fine particulate matter $\left(\mathrm{PM}_{2.5}\right)$ have recently been the focus of several studies as a result of concerns for human health, impacts on ecosystem (Seinfeld and Pandis, 2006) and climate (IPCC, 2013). Due to their lifetime (several days to weeks), $\mathrm{PM}_{2.5}$ and ozone have impacts at both the local and regional level. Therefore, adequate emission control strategies for air quality management need to take into account impacts on different scales.

Photochemical ozone formation is related to precursor molecules: nitrogen oxides $\left(\mathrm{NO}_{x}\right)$, and volatile organic compound (VOC) species, emitted mainly from human activities - such as traffic, industrial production and solvent use - as well as from biogenic emissions. In large European agglomerations, a VOC-limited chemical regime is in general realized (Beekmann and Vautard, 2010), where ozone production is directly related to that of VOC precursors. Secondary aerosol formation is induced by formation of condensable or semivolatile species from precursors like $\mathrm{NO}_{x}, \mathrm{SO}_{2}, \mathrm{NH}_{3}$ and VOCs (Seinfeld and Pandis, 2006). Due to the large number of chemical reactions occurring in different phases, secondary organic aerosol (SOA) formation pathways are still uncertain (e.g., Hallquist et al., 2009), its formation is still difficult to estimate quantitatively (e.g., Hodzic et al., 2010; Zhang et al., 2013), and the contribution of anthropogenic versus biogenic sources are still under debate (e.g., Hallquist et al., 2009; Beekmann et al., 2015). Also, the relative contribution of SOA from traditional anthropogenic VOC precursors (ASOA) and from semivolatile (SVOC) or intermediate volatility (IVOC) organic compounds (SI-SOA) is still under debate and difficult to constrain from field data (as for example discussed in Hayes et al., 2015, for the case of Los Angeles).

Field data provide strong constraints on SOA-related processes. In particular, the relation between $\mathrm{SOA}$ and $\mathrm{O}_{x}\left(\mathrm{O}_{3}+\right.$ $\mathrm{NO}_{2}$ ) has been used to express SOA formation as a function of photochemical products formation (Herndon et al., 2008; Wood et al., 2010; Hayes et al., 2013; Morino et al., 2014). Indeed, in a "VOC-limited regime" in an urban area, such as Paris, VOC oxidation by $\mathrm{OH}$, ozone or $\mathrm{NO}_{3}$ is the rate limiting step for both SOA and ozone or $\mathrm{O}_{x}$ production.

$\mathrm{VOC}+\mathrm{OH} \rightarrow \ldots \rightarrow \ldots \rightarrow \alpha \mathrm{O}_{x}+\beta \mathrm{SOA}+\ldots$

The ratio or slope of SOA vs. $\mathrm{O}_{x}$, given by the term $\beta / \alpha$ represents the ratio of the photochemical production of SOA to the photochemical production of $\mathrm{O}_{x}$, both from VOC oxidation, that is, the SOA yield normalized by current photochemical conditions characterized by the availability of VOC precursors and oxidant agents. It is expected to vary for different VOC species, in particular as a function of their SOA yields, which are for instance large for aromatics and terpenes while low for alkanes and alkenes (Wood et al., 2010). This is reflected in larger SOA vs. $\mathrm{O}_{x}$ slopes observed in Mexico City (typically $0.16 \mu \mathrm{g} \mathrm{m}^{-3} \mathrm{ppb}^{-1}$ ), Los Angeles $\left(0.15 \mu \mathrm{g} \mathrm{m}^{-3} \mathrm{ppb}^{-1}\right.$; Hayes et al., 2013) and Tokyo $\left(0.19 \mu \mathrm{g} \mathrm{m}^{-3} \mathrm{ppb}^{-1}\right.$; Morino et al., 2014), where aromatic emissions are large, than in Houston (typically $0.03 \mu \mathrm{g} \mathrm{m}^{-3} \mathrm{ppb}^{-1}$ ) where petrochemical alkene emissions are large (Wood et al., 2010) (Fig. 1).

The main objective of the MEGAPOLI (Megacities: Emissions, urban, regional and Global Atmospheric POLlution and climate effects, and Integrated tools for assessment and mitigation) Paris campaign in summer 2009 was to determine organic aerosol sources in a post-industrial megacity and in its plume. In this work, we apply the regional chemistry transport model (CTM) CHIMERE (Menut et al., 2013) in order to evaluate the model performance against airborne measurements especially for organic aerosol and to assess the impact of Paris agglomeration emissions on OA (organic aerosol) formation in surrounding regions.

Different configurations of the SOA formation schemes have been implemented into CHIMERE, in particular the volatility basis set (VBS) approach (Robinson et al., 2007; Donahue et al., 2006; Murphy and Pandis, 2009; Lane et al., 2008a). Based on ground level evaluation with data from the MEGAPOLI summer campaign, Zhang et al. (2013) show a better agreement with $\mathrm{OA}$ measurements when taking into account the volatility of primary organic aerosol (POA), the 
existence of additional IVOC, and as the chemical aging of the semivolatile VOC from anthropogenic and biogenic origin. However, SOA was overestimated during long-rangetransport episodes of polluted plumes to the Paris agglomeration. In addition, uncertainties of POA (or SI-VOCs) emissions were made also evident and estimated as at least a factor of 3 (Zhang et al., 2013).

For megacities, sources of organic aerosol are still under debate and need to be quantified (e.g., Molina et al., 2010). While in Beekmann et al. (2015), the local versus advected and the fossil versus non-fossil nature of OA sources within the agglomeration is analyzed, here we focus on additional OA buildup in the agglomeration plume and on its impact on aerosol concentrations in the surrounding of Paris. In the framework of the MEGAPOLI project, airborne measurements were performed with the French ATR-42 aircraft operated by SAFIRE (a CNRS-MétéoFrance-CNES-headed unit) in order to document the evolution of pollutants within the Paris agglomeration pollution plume during the MEGAPOLI summer campaign (Freney et al., 2014). The advantage of the airborne measurements over the ground-based ones is that they allow following the evolution of the city plume over time and space up to $200 \mathrm{~km}$ downwind of the emissions. Data from these flights will be used to extend the model evaluation performed in Zhang et al. (2013) for urban and suburban sites in the Paris agglomeration to plume conditions. The focus is to monitor the buildup of secondary organic aerosol within the plume in relation with tracers of primary emissions and photochemical activity. Among the various formulations that have been derived in the framework of the VBS scheme (for example, Lane et al., 2008a; Murphy and Pandis, 2009; Dzepina et al., 2011; Shrivastava et al., 2013; Zhao et al., 2015, etc.), specifically two are chosen for this paper (as already for Zhang et al., 2013) because they either favor large ASOA or large SI-SOA buildup in the plume. In this way, we intend to address uncertainty linked to the coexistence of different VBS schemes in the formation of different SOA types within the plume. Another important aspect of this paper is to analyze the $\mathrm{OA} / \mathrm{O}_{x}$ ratio, specifically used for model evaluation, as it normalizes SOA formation with respect to photochemical reactivity and precursor load.

The paper is organized as follows. In Sect. 2, the airborne measurements during the MEGAPOLI summer campaign are described. The model configurations and simulation setups for the VBS approach to model POA and SOA are introduced in Sect. 3. The evaluation of model performance for plume simulations is presented in Sect. 4, and the impact on regional air quality is described in Sect. 5. From comparison of different setups of the VBS scheme, uncertainties in the formation of different SOA types in the Paris plume are discussed.

\section{Airborne measurements during the MEGAPOLI summer campaign}

Flight patterns flown during the MEGAPOLI campaign (Fig. 2) consisted of several transects of the pollution plume at increasing distances from the urban area (Freney et al., 2014). Perpendicular flight legs to the plume axis were chosen ranging from 50 to $100 \mathrm{~km}$ in order to sample both the plume and rural background conditions at the lateral plume edges. Taking into account the aircraft autonomy of about $3.5 \mathrm{~h}$, this allowed flying four legs across the plume. The maximal distance for a flight was about $200 \mathrm{~km}$ from the Paris agglomeration center. The flight level was chosen to lie well inside of the well-developed afternoon convective boundary layer, at about $500-700 \mathrm{~m}$ above ground. In addition to measurements inside and outside the Paris plume, each flight included a complete circle around the agglomeration, performed after takeoff and before landing at the CergyPontoise airport. In this work, we focus only on measurements downwind of Paris to study the pollution production from Paris emissions. The measurements started in the early afternoon in order to sample photochemically processed air. Because of a limited number of flight hours, and in line with the principal objective of documenting the photochemical production of pollutants, flights were performed on days with light wind $\left(<3 \mathrm{~m} \mathrm{~s}^{-1}\right)$ and cloud-free weather conditions. For this study, three flights were chosen on the 16, 21 and 29 July, all of which encountered well-pronounced plumes of primary and secondary pollutants. Meteorological conditions for these days were characterized by southerly winds, low wind speed over the agglomeration, elevated temperature and cloudless skies. These conditions favor the accumulation of primary pollutants and photochemical processes leading to the formation of secondary pollutants like $\mathrm{O}_{3}$ and SOA.

An extensive set of gas-phase pollutants, aerosol species and properties were measured on each flight (Freney et al., 2014). For this work, for each flight a complete measurement set of primary pollutants, $\mathrm{BC}$ and $\mathrm{NO}_{x}\left(\mathrm{NO}\right.$ and $\left.\mathrm{NO}_{2}\right)$, and secondary pollutants, $\mathrm{O}_{3}$ and $\mathrm{OA}$, is available and analyzed. Measurement frequencies of all instruments, including the aerosol chemical composition, are rapid enough $(<40 \mathrm{~s})$ to have a relatively good spatial resolution. All measurements during the flights are corrected to temperature $\left(22^{\circ} \mathrm{C}\right)$ and pressure $(950 \mathrm{hPa})$ of the plane (Freney et al., 2014). Thus, compared to other values given in this paper and taken at standard conditions, our values are about $5 \%$ lower. Table 1 summarizes the deployed instruments and the measured concentration levels for these pollutants during these flights. Only measurements at a stable flight altitude are used for this study.

The 30th percentile concentration of a pollutant on the flight legs downwind of Paris is close to the median concentration outside the Paris plume and represents its background level. For $\mathrm{NO}_{x}$ and $\mathrm{BC}$, the 30 th percentile concentrations are $1.11,1.03$ and $1.14 \mathrm{ppb}$, and $0.33,0.49$ and $0.38 \mathrm{\mu g} \mathrm{m}^{-3}$ on 
$\mathrm{BC}\left(\mu \mathrm{g} \mathrm{m}^{-3}\right)$
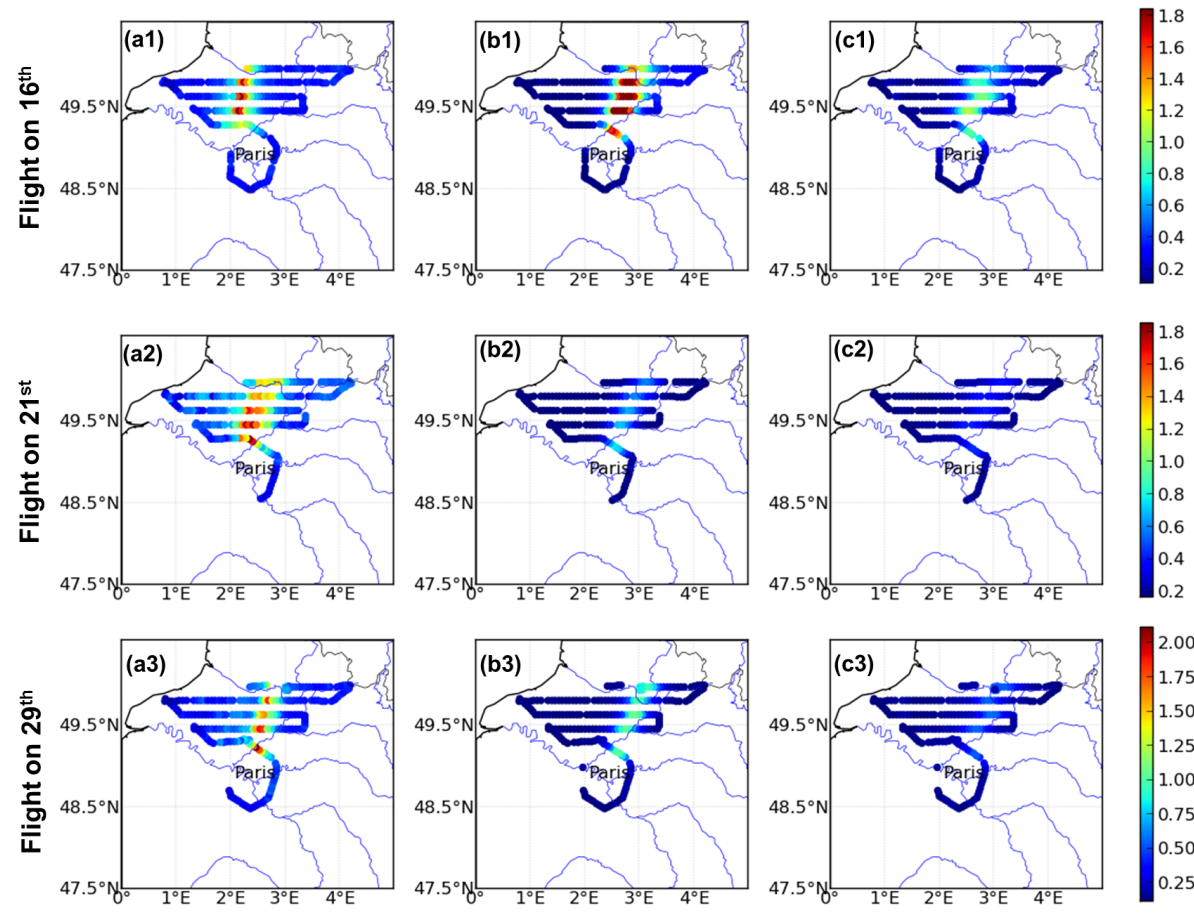

Measurement

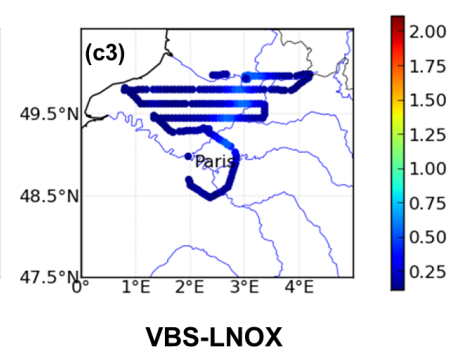

Figure 2. Comparison of measured $(\mathbf{a} 1, \mathbf{a} 2, \mathbf{a 3})$ and modeled BC from VBS-LA (b1, b2, b3) and VBS-LNOX (c1, c2, c3) during the flights on 16, 21 and 29 July, respectively.

Table 1. Airborne chemical instruments deployed, the measurements including the maximum and 30th percentile (P30) of pollutant concentrations by these instruments are used to discuss general findings during the campaign (Freney et al., 2014) and evaluate the model simulations.

\begin{tabular}{|c|c|c|c|c|c|c|c|}
\hline \multirow[t]{2}{*}{ Pollutant } & \multirow[t]{2}{*}{ Instrument } & \multirow[t]{2}{*}{ Time resolution } & \multirow[t]{2}{*}{ Unit } & \multirow[t]{2}{*}{ Statistics } & \multicolumn{3}{|c|}{ Concentration } \\
\hline & & & & & $16 \mathrm{Jul}$ & $21 \mathrm{Jul}$ & $29 \mathrm{Jul}$ \\
\hline \multirow[t]{2}{*}{$\mathrm{NO}_{x}$} & MONA $^{a}$ & $30 \mathrm{~s}$ & $\mathrm{ppb}$ & Max. & 13.5 & 7.98 & 12.2 \\
\hline & & & & P30 & 1.11 & 1.03 & 1.14 \\
\hline \multirow[t]{2}{*}{$\mathrm{O}_{3}$} & UV analyzer ${ }^{b}$ & $30 \mathrm{~s}$ & $\mathrm{ppb}$ & Max. & 62.0 & 79.0 & 62.4 \\
\hline & & & & P30 & 49.0 & 58.0 & 50.0 \\
\hline \multirow[t]{2}{*}{$\mathrm{BC}$} & PSAP $^{c}$ & $1 \mathrm{~s}$ & $\mu \mathrm{g} \mathrm{m}^{-3}$ & Max. & 2.00 & 2.01 & 2.30 \\
\hline & & & & P30 & 0.33 & 0.49 & 0.38 \\
\hline \multirow[t]{2}{*}{$\mathrm{OA}$} & C-ToF-AMS ${ }^{d}$ & $30 \mathrm{~s}$ & $\mu \mathrm{g} \mathrm{m}^{-3}$ & Max. & 5.97 & 12.3 & 7.36 \\
\hline & & & & P30 & 3.87 & 6.47 & 4.13 \\
\hline
\end{tabular}

${ }^{a}$ Measurement of nitrogen on aircraft developed by the Laboratoire Interuniversitaire des Systems Atmosphériques (LISA). NO, $\mathrm{NO}_{2}$ and $\mathrm{NO}_{y}$ are measured (Freney et al., 2014, Supplement).

b Thermal-environmental instruments $\mathrm{O}_{3}$ UV analyzer.

${ }^{\mathrm{c}}$ Radiance research ${ }^{\circledR}$ particulate soot absorption photometer.

d Aerodyne compact time-of-flight aerosol mass spectrometer.

16, 21 and 29 July, respectively (Table 1). The rather homogeneous background pollutant levels (Figs. 2, 3) correspond to the absence of major urban pollution sources in the south of the Paris agglomeration (rural "center" region). The Paris pollution plumes are always clearly identifiable as sharp concentration increases, with continuity on all flight legs at dif- ferent distances from the agglomeration (Figs. 2, 3). The plume half-widths are about several tens of kilometers. Maximum plume concentrations of $\mathrm{NO}_{x}$ and $\mathrm{BC}$ are 13.5, 7.98 and $12.2 \mathrm{ppb}$, and $2.00,2.01$ and $2.30 \mu \mathrm{g} \mathrm{m}^{-3}$, respectively, for the three flights (Table 1). 

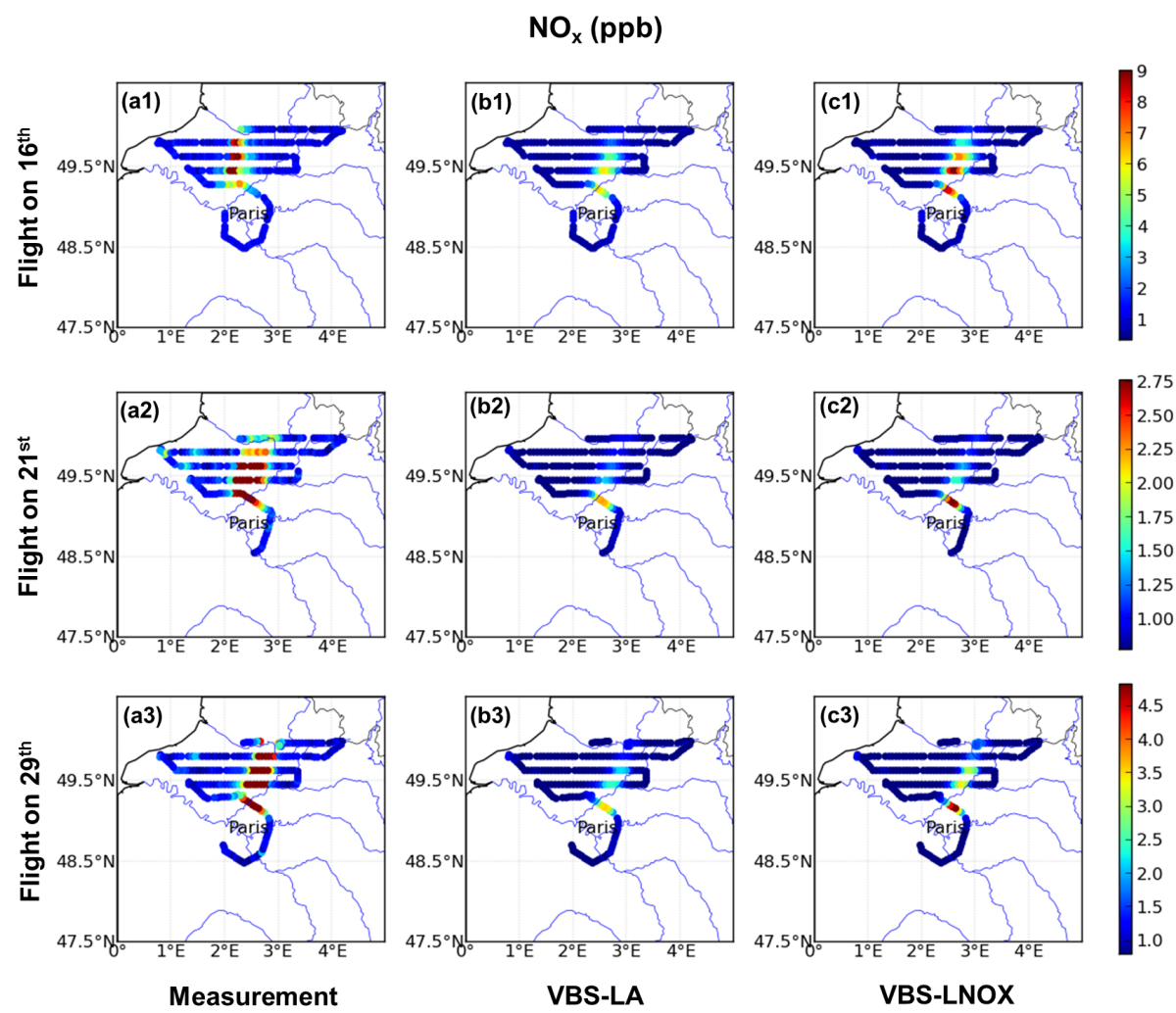

Figure 3. Comparison of measured $(\mathbf{a} 1, \mathbf{a} 2, \mathbf{a 3})$ and modeled $\mathrm{NO}_{x}$ from VBS-LA (b1, b2, b3) and VBS-LNOX (c1, c2, c3) during the flights on 16, 21 and 29 July, respectively.

The maximum plume ozone concentrations are 62.0, 79.0 and $62.4 \mathrm{ppb}$ during these flights, respectively, compared to the 30th percentile (i.e., background) concentrations of 49.0, 58.0 and $50.0 \mathrm{ppb}$ (Table 1). The largest $\mathrm{O}_{3}$ values are observed at the flight leg most distant from the agglomeration, allowing for the longest photochemical processing (Fig. 4). For the 16 July, the transects across the plume show a double maximum and a relative central minimum due to ozone titration by NO.

The background concentrations of $\mathrm{OA}$ are 3.87, 6.47 and $4.13 \mu \mathrm{g} \mathrm{m}^{-3}$, respectively, during these three flights (Table 1, Fig. 5). Maximum plume OA concentrations are 5.97, 12.33 and $7.36 \mu \mathrm{g} \mathrm{m}^{-3}$, respectively. Thus, additional OA buildup within the plume is about $2-6 \mu \mathrm{g} \mathrm{m}^{-3}$ (see also below in Sect. 4.2). Maximum concentrations appear in the three outer flight legs. OA plumes are wider and less homogeneous than primary pollutant ones, which could be due to a secondary organic aerosol production from additional biogenic sources in addition to formation from emissions in the Paris agglomeration.

OA versus $\mathrm{O}_{x}\left(\mathrm{O}_{x}=\mathrm{O}_{3}+\mathrm{NO}_{2}\right)$ plots from measurements on these flights are used to study the ratio of the photochemical productivity of OA and $\mathrm{O}_{x}$ buildup in the plume from Paris emissions, following an approach first proposed by Herndon et al. (2008). In this study, OA is used in- stead of SOA, because it is directly measured. Among OA factors derived from positive matrix factorization (PMF) of AMS (aerosol mass spectrometer) measurements, LV-OOA (low-volatility-oxygenated OA) and SV-OOA (semivolatileoxygenated OA) are commonly attributed to SOA (Hallquist et al., 2009). These LV-OOA and SV-OOA factors contributed on average about $65 \%$ of resolved OA factors and $37 \%$ of the total OA during these three MEGAPOLI flights. HOA (hydrocarbon-like OA) makes up for the remaining $35 \%$ of resolved OA factors and $20 \%$ of the total OA. While the HOA factor is generally attributed to POA, it might partly also correspond to oxidized POA, considered as SOA (Aumont et al., 2012; Cappa and Wilson, 2012), and to cookingrelated OA (Freutel et al., 2013). Using total OA avoids these problems arising from the interpretation of PMF-derived factors.

The Pearson $R$ correlation between $\mathrm{OA}$ and $\mathrm{O}_{x}$ on the three flights on 16, 21 and 29 July is around 0.70 (Table 4, Fig. 6). It indicates a similar ratio of photochemical production of ozone and OA from VOC precursors, though as expected the match between $\mathrm{OA}$ and $\mathrm{O}_{x}$ is not perfect, due to differences in SOA and $\mathrm{O}_{x}$ yields for different VOC precursors. The $\mathrm{OA} / \mathrm{O}_{x}$ slopes for these flights are 0.14 $0.15 \mu \mathrm{g} \mathrm{m}^{-3} \mathrm{ppb}^{-1}$. This result is close to the one obtained from a previous flight study of urban air mass in Mexico City 

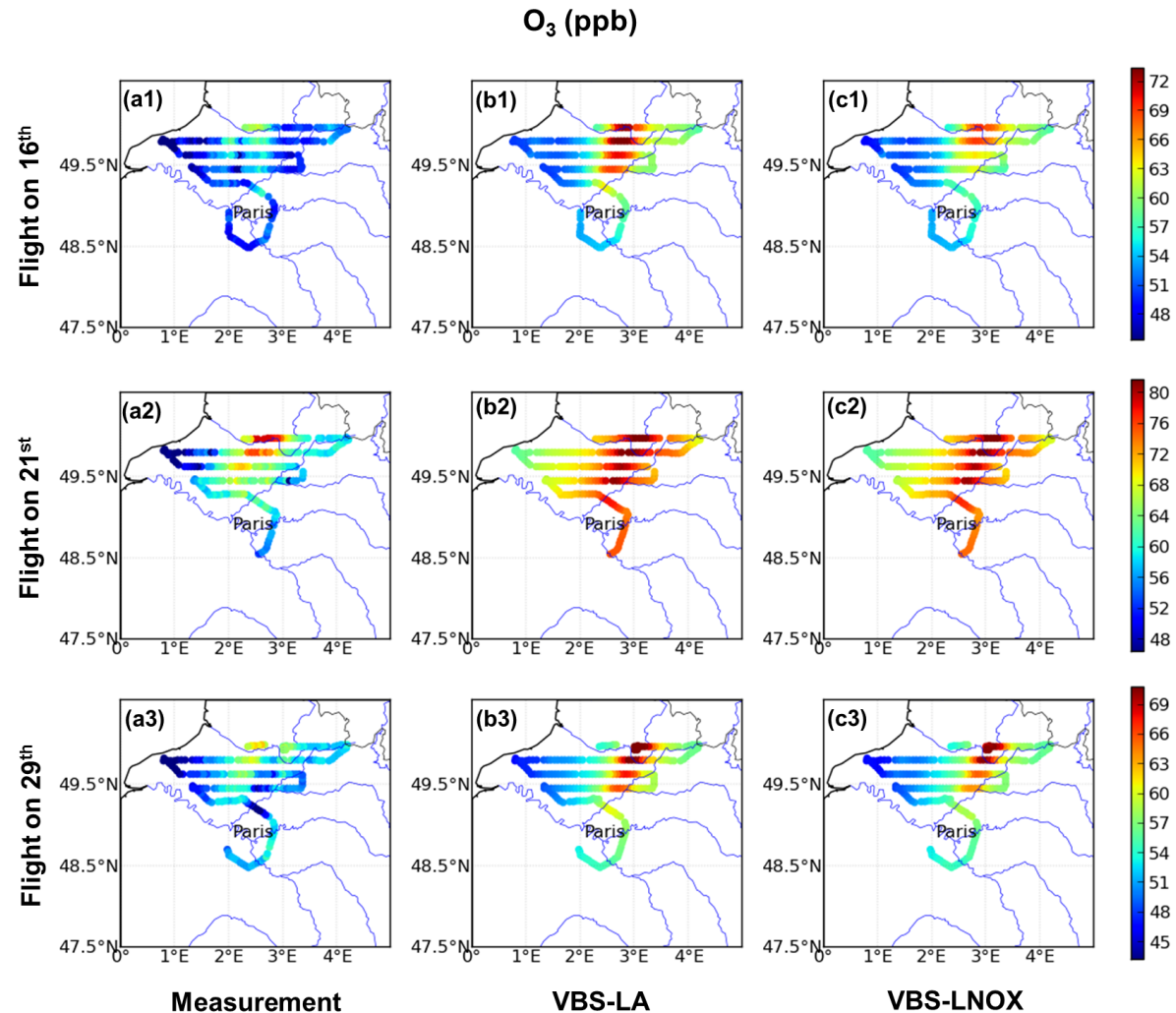

Figure 4. Comparison of measured (a1, a2, a3) and modeled $\mathrm{O}_{3}$ from VBS-LA (b1, b2, b3) and VBS-LNOX (c1, c2, c3) during the flights on 16, 21 and 29 July, respectively.

$\left(0.14-0.15 \mu \mathrm{g} \mathrm{m}^{-3} \mathrm{ppb}^{-1}\right.$, Wood et al., 2010). It is also close to ground-based studies of downwind urban emissions from ground-based measurements in Mexico City (median OOA vs. $\mathrm{O}_{x}$ slope of $0.16 \mu \mathrm{g} \mathrm{m}^{-3} \mathrm{ppb}^{-1}$; Wood et al., 2010), in Los Angeles $\left(0.15 \mu \mathrm{g} \mathrm{m}^{-3} \mathrm{ppb}^{-1}\right.$; Hayes et al., 2013) and in Tokyo (0.19 $\mu \mathrm{g} \mathrm{m}^{-3} \mathrm{ppb}^{-1}$; Morino et al., 2014).

\section{Simulations}

\subsection{Model configuration}

In this work, we used the CHIMERE v2008b model (see http: //www.lmd.polytechnique.fr/chimere/) (Vautard al., 2001; Bessagnet et al., 2009; Menut et al., 2013), widely used for operational regional air quality forecasts (Honoré et al., 2008; Zhang et al., 2012) and simulations in Europe (e.g., Beekmann and Vautard, 2010; Sciare et al., 2010). With a few exceptions (noted below), the same model configuration as in Zhang et al. (2013) was set up. Two nested domains are applied: a continental domain covering Europe with a resolution of $0.5^{\circ}\left(35-57.5^{\circ} \mathrm{N}, 10.5^{\circ} \mathrm{W}-22.5^{\circ} \mathrm{E}\right)$ and a regional domain over northern France covering all the flight patterns during this campaign with a resolution of $3 \mathrm{~km}$ (called MEG3 domain). Eight hybrid-sigma vertical layers are used, with the first layer extending from the ground to about $40 \mathrm{~m}$, and a model top at $500 \mathrm{hPa}$. Tropospheric photochemistry is represented using the reduced MELCHIOR chemical mechanism (Lattuati, 1997; Derognat et al., 2003), including 120 reactions and 44 prognostic gaseous species. For the simulation of the particulate phase, eight bins of particulate sizes are used in the model with diameters ranging from 0.04 to $10 \mu \mathrm{m}$. The thermodynamic equilibrium of the inorganic species (sulfate, nitrate, and ammonium) between the gas and particle phase is interpolated from a tabulation calculated with the ISORROPIA model (Nenes et al., 1998). The evaporation and condensation processes related to departures from the thermodynamic equilibrium are kinetically controlled.

Two SOA formation mechanisms are used and are described in more detail in Sect. 3.2. For SI-SOA (SOA from oxidation of primary semivolatile and intermediate volatile VOCs, previously referred to as OPOA in Zhang et al., 2013) formation, both mechanisms use the VBS formulation as described in Robinson et al. (2007). For traditional anthropogenic and biogenic SOA (ASOA and BSOA) formation from VOC precursors, one uses the classical single-step oxidation scheme (Pun et al., 2006; Bessagnet et al., 2009) and the other one a volatility basis set (VBS) scheme with differences in high- $\mathrm{NO}_{x}$ and low- $\mathrm{NO}_{x}$ parametrizations. The VBS approach is implemented in the model as in Murphy and Pandis (2009) and Lane et al. (2008a). In our work, BSOA 

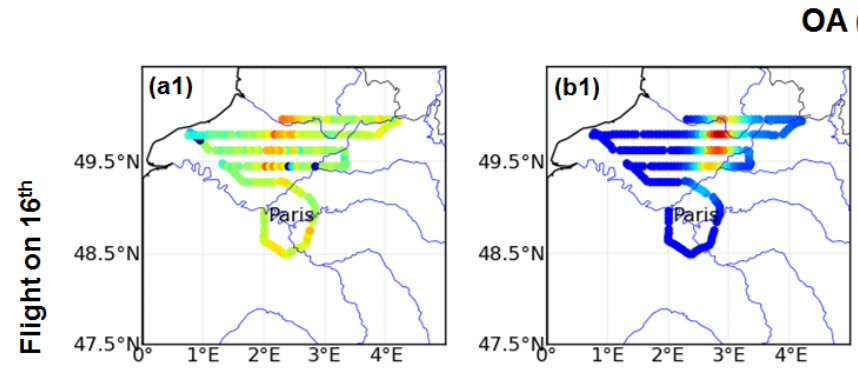

$\mathrm{OA}\left(\mu \mathrm{g} \mathrm{m}^{-3}\right)$
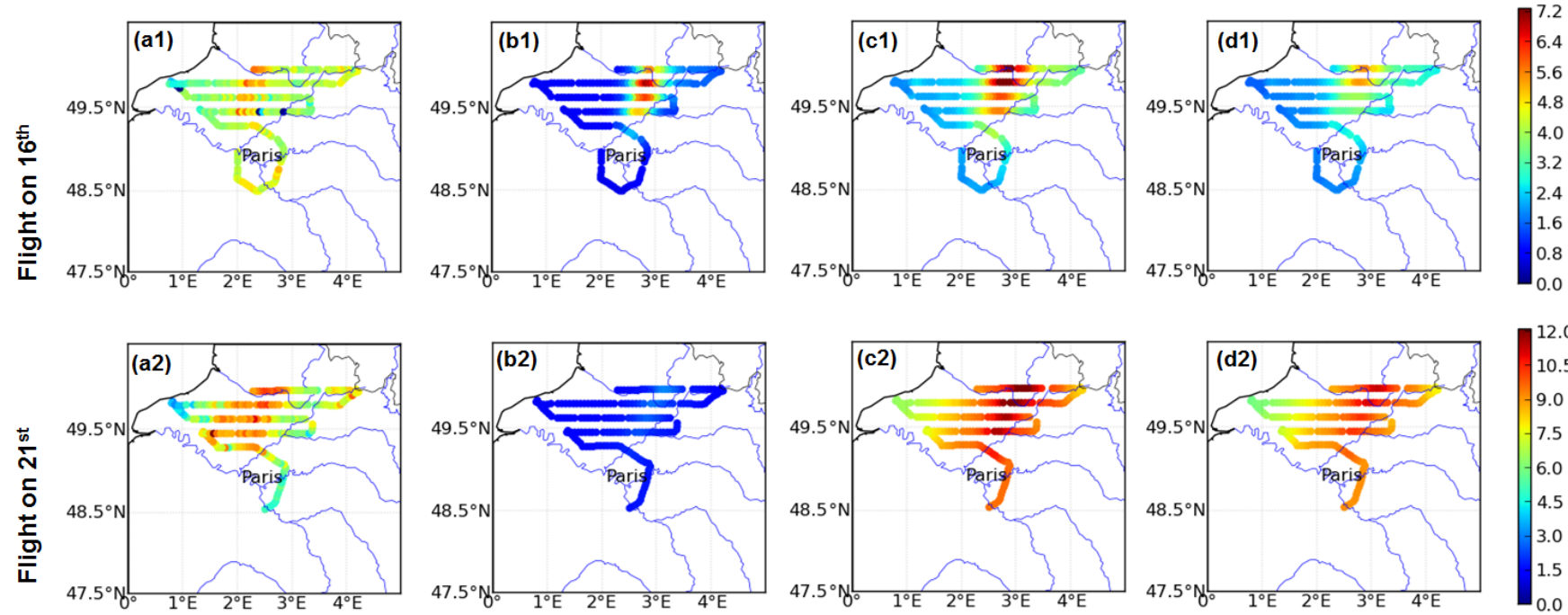

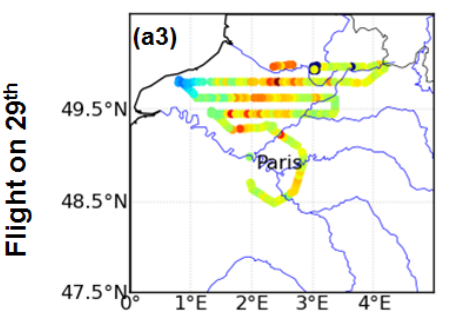

Measurement

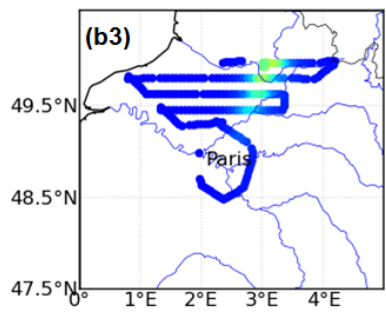

VBS-LA
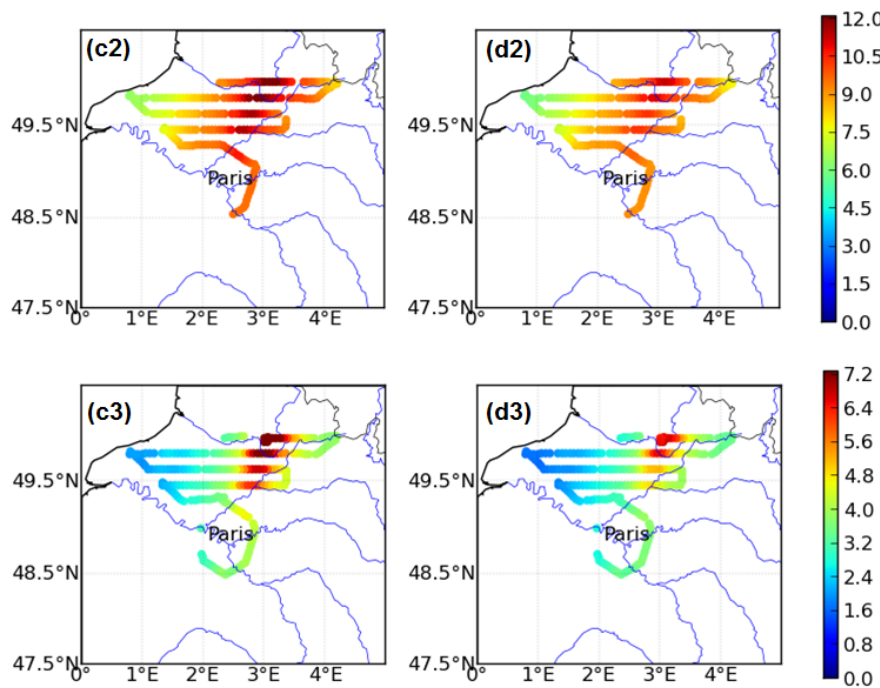

VBS-LNOX

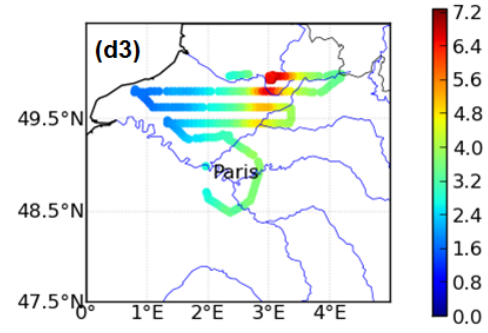

VBS-HNOX

Figure 5. Comparison of measured (a1, a2, a3) and modeled OA from VBS-LA (b1, b2, b3), VBS-LNOX (c1, c2, c3) and VBS-HNOX (d1, d2, d3) during the flights on 16, 21 and 29 July, respectively.

gas-phase aging is also included with the same rate constant as for ASOA $\left(1 \times 10^{-11} \mathrm{~mol} \mathrm{~cm}^{3} \mathrm{~s}^{-1}\right)$. Gas-phase chemical aging of BSOA is supported by laboratory (see in Zhao et al., 2015) and box model experiments with the very detailed GECKO-A mechanism (Generator of Explicit Chemistry and Kinetics of Organics in the Atmosphere; Valorso et al., 2011). In Zhang et al. (2013), it had been shown that including BSOA aging was necessary to reproduce several OA peaks occurring during the summer campaign at Paris urban sites in the model.

For the large domain, anthropogenic gas-phase emissions are calculated from EMEP (European Monitoring and Evaluation Programme)annual totals (http://www.ceip. at/emission-data-webdab/), while black carbon (BC) and primary organic aerosol (POA) are prescribed from an emissions inventory prepared by Laboratoire d'Aérologie (LA) (Junker and Liousse, 2008). In the different simulation setup's in Sect. 3.2, emissions for the inner domain MEG3 over northern France are either taken from the same EMEP-LA inventory or from an alternative inventory specifically designed for the MEGAPOLI project, the Airparif-TNO-MEGAPOLI inventory, in which the refined Paris emissions from Airparif with a resolution of $1 \mathrm{~km}$ are integrated into the Europeanwide TNO inventory (Timmermans et al., 2013). In this latter inventory, BC and POA emissions for the Paris agglomeration are about 2 and 3 times lower than in the EMEPLA inventory, respectively, and VOC emissions are about a third lower, while $\mathrm{NO}_{x}$ emissions are similar. These differences are explained by use of spatial downscaling techniques in the EMEP-LA inventory using proxies that generally tend to overestimate megacity or urban emissions, while the Airparif-TNO-MEGAPOLI inventory is constructed following a bottom-up approach (Timmermans et al., 2013). Both inventories are affected by additional uncertainties in activities and related emission factors. Cooking emissions, which have been shown to be significant for the Paris agglomeration (Freutel et al., 2013; Crippa et al., 2013) are not included in either of these emission inventories. In this work, we assume that differences in BC and POA emissions in both inventories span the range of uncertainty for these emissions in the Paris region. This is compatible with the Petetin et al. (2015) study which evaluates these emission inventories with respect to ground-based measurements within the agglomeration and ground-based ones around it. As explained 

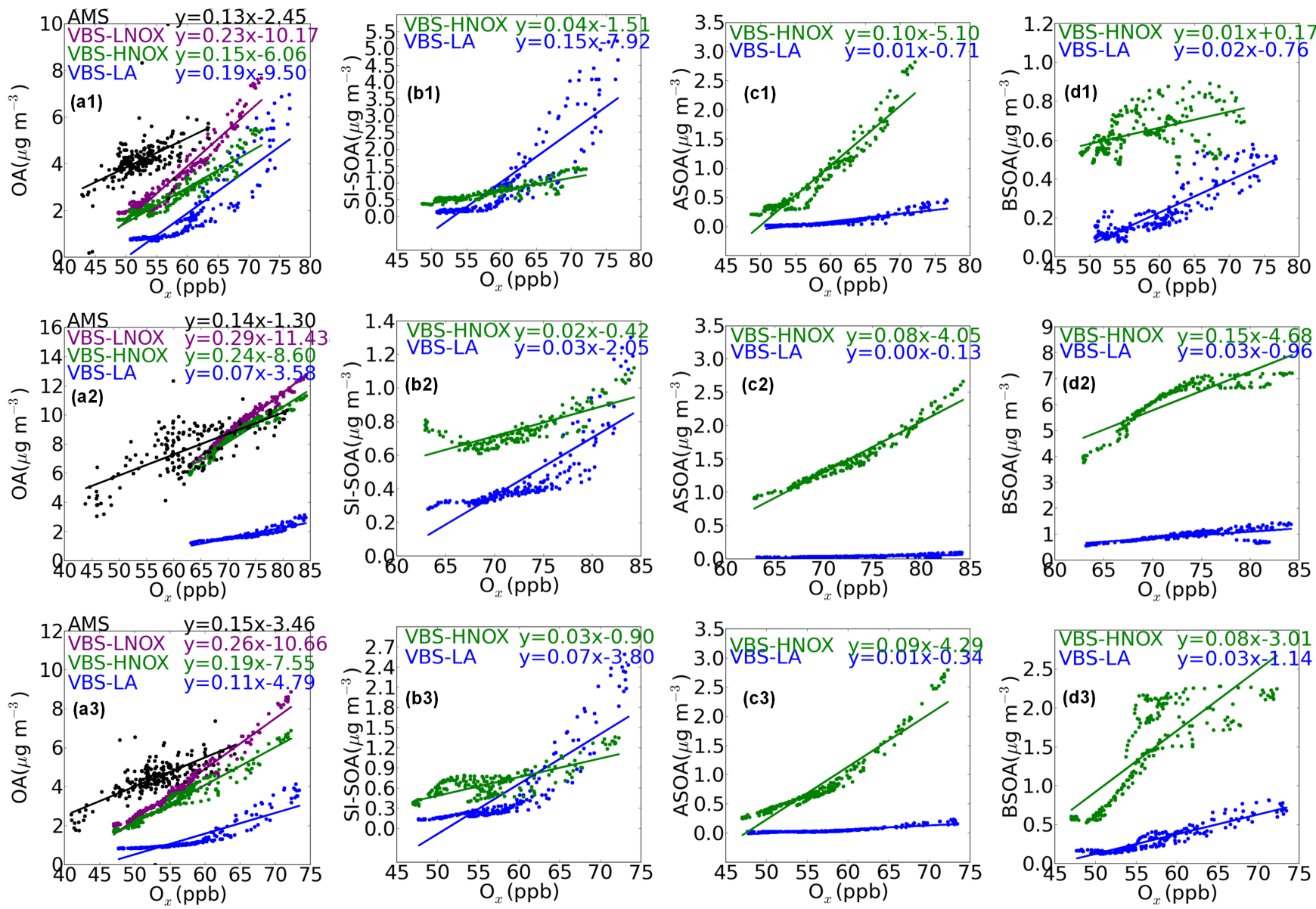

Figure 6. OA vs. $\mathrm{O}_{x}(\mathbf{a} 1, \mathbf{a 2}, \mathbf{a 3})$, SI-SOA vs. $\mathrm{O}_{x}(\mathbf{b 1}, \mathbf{b 2}, \mathbf{b 3})$, ASOA vs. $\mathrm{O}_{x}(\mathbf{c 1}, \mathbf{c 2}, \mathbf{c 3})$ and BSOA (d1, d2, d3) vs. $\mathrm{O}_{x}$ during the flights on 16, 21 and 29 July, respectively. For OA vs. $\mathrm{O}_{x}(\mathbf{a 1}, \mathbf{a} 2, \mathbf{a 3})$, results from the measurement, VBS-LA, VBS-LNOX and VBS-HNOX are presented. For others, only results from VBS-LA and VBS-HNOX are presented.

in more detail in Zhang et al. (2013), POA/SVOC emission factors for the main source in summer, traffic, are obtained from laboratory measurements under low level of dilution (with OA loading of $1000 \mu \mathrm{g} \mathrm{m}^{-3}$ ). Under these conditions, the POA/SVOC emissions are emitted mostly in the particle phase. A volatility distribution following Robinson et al. (2007) was affected to these emissions. Additional IVOC emissions (factor 1.5 of POA/SVOC) were also considered according to Robinson et al. (2007).

Biogenic emissions are calculated using the MEGAN (Model of Emissions of Gases and Aerosols from Nature) model data and parametrizations (Guenther et al., 2006). Meteorological fields are simulated with the MM5 mesoscale model (PSU/NCAR mesoscale model; Dudhia, 1993). Boundary conditions are taken from a monthly climatology of the LMDz-INCA2 and LMDz-AERO general circulation models (Hauglustaine et al., 2004).

\subsection{Simulation configurations}

Here, a brief summary on the three distinct simulation configurations used in this study is given. They are intended to take into account both uncertainties in SOA formation schemes and in POA/SI-VOC emissions.

- The VBS-LNOX (low-NO $\mathrm{NO}_{x}$ ) simulation, in which all SI-SOA, ASOA and BSOA are affected by chemical aging with the VBS approach. High SOA yields under low- $\mathrm{NO}_{x}$ conditions (Murphy and Pandis, 2009; Lane et al., 2008a) are used for both simulation domains (the same as the so-called VBS-MPOLI simulation in Zhang et al., 2013; see Table 2), assuming that most of the OA is advected to the Paris agglomeration from outside (Petetin et al., 2014) and probably formed under low- $\mathrm{NO}_{x}$ conditions. Usually, a limiting $\mathrm{VOC} / \mathrm{NO}_{x}$ ratio of 3 and $10 \mathrm{ppbC} \mathrm{ppb}^{-1}$ is used to discern a high- and a low- $\mathrm{NO}_{x}$ regime, respectively (Lane et al., 2008b). While the ratio of $10 \mathrm{ppbCpp}^{-1}$ is close to or above the value for most of northern France, indicating that it is close to 
Table 2. Secondary organic aerosol (SOA) mass yields used in this work. These yields are for surrogate VOC species with saturation concentrations of $1,10,100$ and $1000 \mu \mathrm{g} \mathrm{m}^{-3}$ at $298 \mathrm{~K}$ (Murphy and Pandis, 2009).

\begin{tabular}{|c|c|c|c|c|c|c|c|c|}
\hline \multirow[t]{2}{*}{ VOCs } & \multicolumn{4}{|c|}{ VBS-LNOX with low- $\mathrm{NO}_{x}$ condition } & \multicolumn{4}{|c|}{ VBS-HNOX with high-NO ${ }_{x}$ condition } \\
\hline & 1 & 10 & 100 & 1000 & 1 & 10 & 100 & 1000 \\
\hline ALK $4^{\mathrm{a}}$ & 0 & 0.075 & 0 & 0 & 0 & 0.0375 & 0 & 0 \\
\hline ALK5 $5^{\mathrm{b}}$ & 0 & 0.3 & 0 & 0 & 0 & 0.15 & 0 & 0 \\
\hline OLE $1^{\mathrm{c}}$ & 0.0045 & 0.009 & 0.06 & 0.225 & 0.0008 & 0.0045 & 0.0375 & 0.15 \\
\hline OLE $2^{d}$ & 0.0225 & 0.0435 & 0.129 & 0.375 & 0.003 & 0.0255 & 0.0825 & 0.27 \\
\hline $\mathrm{ARO}^{\mathrm{e}}$ & 0.075 & 0.225 & 0.375 & 0.525 & 0.003 & 0.165 & 0.3 & 0.435 \\
\hline $\mathrm{ARO} 2^{\mathrm{f}}$ & 0.075 & 0.3 & 0.375 & 0.525 & 0.0015 & 0.195 & 0.3 & 0.435 \\
\hline TERP' & 0.1073 & 0.0918 & 0.3587 & 0.6075 & 0.012 & 0.1215 & 0.201 & 0.507 \\
\hline ISOP $^{h}$ & 0.009 & 0.03 & 0.015 & 0 & 0.0003 & 0.0225 & 0.015 & 0 \\
\hline
\end{tabular}

a $n$-Pentane, $n$-hexane, branched C5-C6 alkanes, cyclopentane, trimethyl butane, trimethyl pentane, isopropyl alcohol, $n$-propyl alcohol.

b C7-C22 n-alkanes, C6-C16 cycloalkanes, branched/unspeciated C8-C18 alkanes.

c Propene, $\mathrm{C} 4-\mathrm{C} 15$ terminal alkanes.

d Isobutene, C4-C15 internal alkenes, C6-C15 cyclic or diolefins, styrenes.

e Toluene, benzene, ethylbenzene, C9-C13 monosubstituted benzenes.

f Xylenes, ethyl toluenes, dimethyl and trimethyl benzenes, ethylbezenes, naphthalene, $\mathrm{C} 8-\mathrm{C} 13$ di-, tri-, tetra-, penta-, and hexasubstituted benzenes, unspeciated $\mathrm{C} 10-\mathrm{C} 12$ aromatics.

$\mathrm{g} \alpha$-Pinene and sabinene, $\beta$-pinene and $\delta 3$-carene, limonene, ocimene and myrcene.

${ }^{\mathrm{h}}$ Isoprene.

a low- $\mathrm{NO}_{x}$ regime, it is close to or below the ratio of $3 \mathrm{ppbC} \mathrm{ppb}^{-1}$ on the north of Paris in the plume region (Fig. $\mathrm{S} 1$ in the Supplement). This low- $\mathrm{NO}_{x}$ configuration is thus expected to overestimate ASOA formation in the Paris pollution plume under high- $\mathrm{NO}_{x}$ conditions around Paris. The emission inventory for the MEG3 domain is the specific MEGAPOLI inventory.

- The VBS-HNOX (high- $\mathrm{NO}_{x}$ ) simulation, in which lower SOA yields under high- $\mathrm{NO}_{x}$ conditions (Murphy and Pandis, 2009; Lane et al., 2008a) are used for the inner MEG3 domain (see Table 2). This is more realistic for SOA formation in its plume close to the Paris agglomeration than in low- $\mathrm{NO}_{x}$ conditions. The low- $\mathrm{NO}_{x}$ condition is still applied on the continental domain for background OA simulation. All other model settings are equal to the VBS-LNOX configuration. Although using high- $\mathrm{NO}_{x}$ conditions with lower yields, which are more realistic for the plumes from Paris emissions, this configuration might still overestimate ASOA formation in the plume following the new ASOA yields fitted to laboratory experiments in SOA formation schemes described in Zhao et al. (2015).

- The VBS-LA simulation (same as VBS-T1 simulation in Zhang et al., 2013), in which a single-step oxidation scheme (Pun et al., 2006) is used for traditional ASOA and BSOA formation, as is VBS scheme for SISOA formation and for the other two configurations. The EMEP-LA emission inventory with 3 times larger $\mathrm{POA} / \mathrm{SI}-\mathrm{VOC}$ emissions is used for the inner MEG3 domain. The fact that POA/SI-VOC emissions are 3 times larger and the absence of chemical aging for
ASOA will favor SI-SOA with respect to ASOA formation.

\section{Model evaluation with airborne measurements}

In this section, modeling results of $\mathrm{NO}_{x}, \mathrm{BC}, \mathrm{O}_{x}$, and $\mathrm{OA}$ are presented and compared to the airborne measurements at the same location and time. Outputs from simulations are interpolated to the exact flight location and time. $\mathrm{NO}_{x}$ and $\mathrm{BC}$ are compared as primary urban tracers to indicate the location of the Paris plume in observations and in simulations. Only the VBS-LNOX simulations are used for $\mathrm{BC}, \mathrm{NO}_{x}$ and $\mathrm{O}_{x}$, because a change of the SOA yields does not affect the simulation of the concentrations of these species between the VBS-LNOX and VBS-HNOX simulations. The evaluation with the VBS-LA simulations gives an insight on effects of emission uncertainties. Individual species comparisons are presented in Sect. 4.1 while model observation comparisons of the $\mathrm{OA} / \mathrm{O}_{x}$ ratio are presented in Sect. 4.2. For each of the four to five transects through the pollution plume of a flight, the simulated and observed maximum concentrations are depicted and averaged over all transects of a flight. The same procedure is applied for the 30th percentiles (P30) over each transect, considered as representative for background conditions outside of the plume.

\subsection{Individual species model to observation comparisons}

The qualitative inspection of simulated and observed $\mathrm{BC}$ plumes shows that the plume direction is correctly simulated on 21 and $29 \mathrm{July}$, while a difference of about $20^{\circ}$ occurs on 
Table 3. Model statistics for maximum and 30th percentile (P30) of pollutant concentrations from VBS-LNOX (and VBS-HNOX for OA as well) and VBS-LA.

\begin{tabular}{|c|c|c|c|c|c|c|c|c|}
\hline \multirow[t]{2}{*}{ Pollutant } & \multirow[t]{2}{*}{ Unit } & \multirow[t]{2}{*}{ Statistics } & \multicolumn{3}{|c|}{ VBS-LNOX } & \multicolumn{3}{|c|}{ VBS-LA } \\
\hline & & & $16 \mathrm{Jul}$ & $21 \mathrm{Jul}$ & $29 \mathrm{Jul}$ & $16 \mathrm{Jul}$ & $21 \mathrm{Jul}$ & $29 \mathrm{Jul}$ \\
\hline \multirow[t]{2}{*}{$\mathrm{NO}_{x}$} & $\mathrm{ppb}$ & Max. & 9.18 & 2.82 & 4.92 & 6.16 & 2.25 & 3.54 \\
\hline & & P30 & 0.47 & 0.61 & 0.55 & 0.62 & 0.67 & 0.63 \\
\hline \multirow[t]{2}{*}{$\mathrm{BC}$} & $\mu \mathrm{g} \mathrm{m}^{-3}$ & Max. & 1.3 & 0.52 & 0.69 & 2.41 & 0.77 & 1.08 \\
\hline & & P30 & 0.16 & 0.18 & 0.16 & 0.11 & 0.15 & 0.11 \\
\hline \multirow[t]{2}{*}{$\mathrm{O}_{3}$} & $\mathrm{ppb}$ & Max. & 69.5 & 83.3 & 70.7 & 74.9 & 83.3 & 72.2 \\
\hline & & P30 & 53.3 & 69.3 & 53.0 & 53.6 & 69.7 & 53.3 \\
\hline \multirow{2}{*}{$\mathrm{O}_{x}$} & $\mathrm{ppb}$ & Max. & 72.1 & 84.2 & 72.2 & 76.7 & 84.2 & 73.4 \\
\hline & & P30 & 53.7 & 69.8 & 53.4 & 54.1 & 70.3 & 53.8 \\
\hline \multirow[t]{2}{*}{$\mathrm{OA}$} & $\mu \mathrm{g} \mathrm{m}^{-3}$ & Max. & 7.66 & 12.74 & 8.87 & 6.97 & 3.13 & 4.14 \\
\hline & & P30 & 2.28 & 8.77 & 3.09 & 0.81 & 1.55 & 0.91 \\
\hline \multirow[t]{2}{*}{$\mathrm{OA}^{*}$} & $\mu \mathrm{g} \mathrm{m}^{-3}$ & Max. & 5.48 & 11.31 & 6.88 & & & \\
\hline & & P30 & 1.95 & 8.35 & 2.85 & & & \\
\hline
\end{tabular}

$\mathrm{OA}^{*}$ : OA from VBS-HNOX simulations.

16 July (Fig. 2). This will have little influence on the study of the OA impact from Paris on its surroundings due to the rather circular structure of the agglomeration (Shaiganfar et al., 2015). In both the modeled fields and observations, the largest concentrations appear close to the Paris agglomeration during these three flights.

The modeled maximum $\mathrm{BC}$ concentrations from VBSLNOX are underestimated by $-0.7(-35 \%),-1.5(-74 \%)$ and $-1.6 \mu \mathrm{g} \mathrm{m}^{-3}(-70 \%)$ with respect to the measurement, respectively, for 16,21 , and 29 July, while they are overestimated by $0.4(21 \%)$ and underestimated by $-1.2(-62 \%)$ and $-1.2 \mu \mathrm{g} \mathrm{m}^{-3}(-53 \%)$ from VBS-LA, respectively (Tables 3, S1; Fig. 2). Thus, for the last two flights, the BC underestimation appears for both emission inventories. An average underestimation of plume BC measurements by $-20 \%$ (over 10 flights during July 2009) was already noticed by Petetin et al. (2015), which could be attributed to errors in emission inventories, uncertainty in measurements and in the choice of the mass specific absorption coefficient (Petetin et al., 2015). Our study focusses on 3 days with particularly low wind speeds with variable wind direction during morning hours in the Paris agglomeration, allowing for primary pollution buildup and subsequent secondary pollution buildup in the plume. As shown in Petetin et al. (2015), it turns out that the meteorological model (MM5, but similar results are obtained for WRF) forcing the CTM simulations is not capable of simulating these wind direction variations for two of the 3 flight days, on 21 and 29 July, thus underestimating the pollution accumulation in the Paris region and subsequently in the plume. The modeled 30th percentile BC concentrations taken as representative for background concentrations are also underestimated by $-0.17(-51 \%),-0.31(-62 \%)$ and $-0.22 \mu \mathrm{g} \mathrm{m}^{-3}(-59 \%)$ from VBS-LNOX and by -0.22 $(67 \%),-0.34(-69 \%)$ and $-0.27 \mu \mathrm{g} \mathrm{m}^{-3}(-71 \%)$ from
VBS-LA, respectively, during these flights (Tables 3, S1; Fig. 2).

Similar to BC, VBS-LNOX underestimates $\mathrm{NO}_{x}$ concentrations by $-4.3(-32 \%),-5.2(-65 \%)$ and $-7.3 \mathrm{ppb}$ $(-60 \%)$ for the maximum concentrations and by -0.64 $(-58 \%),-0.42(-41 \%)$ and $-0.59 \mathrm{ppb}(-52 \%)$ for the background concentrations with respect to the measurements (Tables 3, S1; Fig. 3). VBS-LA shows slightly more underestimation by $-7.3(-54 \%),-5.3(-72 \%)$ and $-8.7(-71 \%)$ ppb for the maximum concentrations and slightly less underestimated for the background concentrations by -0.57 $(-51 \%),-0.36(-35 \%)$ and $-0.51(56 \%)$ ppb (Tables 3, $\mathrm{S} 1)$. Also similar to $\mathrm{BC}$, the modeled $\mathrm{NO}_{x}$ maximum concentrations for both simulations are located close to the Paris agglomeration (Figs. 2, 3).

The modeled $\mathrm{O}_{3}$ concentrations are slightly overestimated with respect to the measured $\mathrm{O}_{3}$ concentrations, by 7.5 $(12 \%), 4.3(5 \%)$ and $8.3 \mathrm{ppb}(13 \%)$ from VBS-LNOX and $12.9(21 \%), 4.3(5 \%)$ and $9.8 \mathrm{ppb}(16 \%)$ from VBS-LA for the maximum concentrations, and by $4.3(9 \%), 11.3$ $(20 \%)$ and $3.0 \mathrm{ppb}(6 \%)$ from VBS-LNOX and $4.6(9 \%)$, $11.7(20 \%)$ and $3.3 \mathrm{ppb}(7 \%)$ from VBS-LA for the background concentrations during the three flights, respectively (Tables 3, S1; Fig. 4). Note that, for $\mathrm{O}_{x}$, the concentrations can be slightly less overestimated than for $\mathrm{O}_{3}$ by, respectively, $3.0(6 \%), 11.0(19 \%)$ and $1.8 \mathrm{ppb}(4 \%)$ from VBSLNOX and $3.4(7 \%), 11.4(19 \%)$ and $2.1 \mathrm{ppb}(4 \%)$ from VBS-LA for the background concentrations due to the opposite sign in measured $\mathrm{O}_{3}$ and $\mathrm{NO}_{x}$ differences (Tables 1, 3, S1; Fig. S2) and sometimes for the maximum concentrations by $8.5(13 \%), 3.6(4 \%), 8.0 \mathrm{ppb}(12 \%)$ from VBS-LNOX and $13.1(21 \%), 3.5(4 \%)$ and $9.2 \mathrm{ppb}(14 \%)$ from VBSLA. Similar to the observations, the modeled maximum $\mathrm{O}_{3}$ and $\mathrm{O}_{x}$ levels are located farthest from the agglomeration. 
Differences between VBS-LNOX and VBS-LA are apparently small. The rather correct simulation of $\mathrm{O}_{3}$ and $\mathrm{O}_{x}$ in spite of the $\mathrm{NO}_{x}$ underestimation is less astonishing in light of the following discussion about $\mathrm{NO}_{x}-\mathrm{OH}$ relationships.

Direct comparisons for POA are not shown here because of the uncertainty in HOA factors from the PMF analysis, and because of the incomplete match between HOA and POA. However, the $\mathrm{BC}$ underestimation in simulations lets us also expect a POA underestimation.

Consequences of these underestimations in primary pollutants on the buildup of secondary pollutants are briefly discussed here.

- First, as shown above for BC, the underestimation is alleviated in the alternative VBS-LA simulation with larger BC (and POA) emissions. Thus, unexpressed uncertainty in meteorological data is partly taken into account by that in emissions.

- Second, the use of OA vs. $\mathrm{O}_{x}$ slopes for evaluation of the SOA production efficiency normalizes the effect of errors in primary pollutants, as in Eq. (1); it merely depends on the ratio of the product yields. This is why the use of this ratio is important for this study.

- Third, in a VOC-limited regime, as is characteristic for the Paris region (e.g., Deguillaume et al., 2008), the rate of secondary pollutant buildup is far from proportional to the primary precursor concentration. On the contrary, in the extreme case that $\mathrm{NO}_{x}$ compounds represent the only $\mathrm{OH}$ loss, $\mathrm{NO}_{x}$ and $\mathrm{OH}$ concentrations are inversely proportional (e.g., Kleinman et al., 1997). When assuming a constant ratio in primary pollutants, the flux in Eq. (1) is then independent of VOC concentrations and only depends on the production rate of odd hydrogen radicals $\left(\mathrm{OH}+\mathrm{HO}_{2}+\mathrm{RO}_{2}\right)$.

The measured OA plume is correlated with the measured BC plume on 16 July, while it appears translated to the west on 21 and 29 July, as is also the ozone plume (Figs. 3-5). This is probably due to an additional contribution from other sources besides the Paris emissions, such as background levels from regional contributions related to both anthropogenic and biogenic sources. In the simulations, $\mathrm{OA}, \mathrm{O}_{3}, \mathrm{BC}$, and $\mathrm{NO}_{x}$ plumes coincide for all dates indicating a contribution from the Paris emissions. As expected from results in Zhang et al. (2013) for urban and suburban Paris sites, the VBSLA simulation with single-step oxidation scheme for ASOA and BSOA formation generally underestimates OA measurements, in particular for the background concentrations, by up to $80 \%$ (Fig. 5). A slight overestimation of $1 \mu \mathrm{g} \mathrm{m}^{-3}$ is observed in the plume for the maximum concentration during the flight on 16 July. This is related to high POA and SI-SOA contributions of up to $70 \%$ to the total OA concentrations in the plume (Figs. S3, S4). Thus, apparently, the increased plume SI-SOA buildup due to increased POA emissions in the agglomeration is able to overcompensate the lack in background SOA at least for this day.

Simulations with the VBS-HNOX configuration show lower plume concentrations than those with the VBS-LNOX configuration, because of lower yields in SOA formation in the inner MEG3 domain. Background simulations are similar for both simulations corresponding to low- $\mathrm{NO}_{x}$ yields chosen for both simulation configurations in the larger domain. The maximum concentration of OA simulated with VBS-LNOX is overestimated with respect to the measurement by $1.7(28 \%), 0.4(3 \%)$ and $1.5 \mu \mathrm{g} \mathrm{m}^{-3}(21 \%)$ on 16,21 and 29 July, respectively, while it fits well with the observations in VBS-HNOX, being slightly underestimated by $-0.5(-8 \%),-1(-8 \%)$ and $-0.5 \mu \mathrm{g} \mathrm{m}^{-3}(-7 \%)$ (Tables 3, S1; Fig. 5). The modeled OA background concentrations are underestimated both on 16 and 29 July by VBSLNOX by, respectively, $-1.6(-41 \%)$ and $-1.0 \mu \mathrm{g} \mathrm{m}^{-3}$ $(-25 \%)$ and by VBS-HNOX by, respectively, $-1.9(-50 \%)$ and $-1.4 \mu \mathrm{g} \mathrm{m}^{-3}(-33 \%)$. They are overestimated with both configurations on 21 July by $2.3(36 \%)$ and $1.9 \mu \mathrm{g} \mathrm{m}^{-3}$ (29\%), respectively (Tables $3, \mathrm{~S} 1)$. All in all, simulated and observed OA concentrations are rather similar, which is a satisfying result in light of often very large model to observation differences reported in literature (e.g., Sciare et al., 2010, for the Paris region). However, as the primary pollutants are generally underestimated by the model, this might be the result of compensating errors for different OA compounds. In a later section (Sect. 4.3), we will thus rely on OA versus $\mathrm{O}_{x}$ slopes in the Paris plume for further analysis.

\subsection{OA plume buildup}

First, the plume productions of OA (and of $\mathrm{O}_{x}$ ) are derived here from the difference between maximum and background (30th percentile) concentrations over flight transects as given in the last section. $\mathrm{O}_{x}$ is preferred here with respect to $\mathrm{O}_{3}$ since it is not affected by titration with NO. For the 3 flight days (16, 21 and 29 July), the measured values of OA plume buildup are $2.1,5.9$ and $3.2 \mu \mathrm{g} \mathrm{m}^{-3}$, respectively, while they are 5.4, 4.0 and $5.8 \mu \mathrm{g} \mathrm{m}^{-3}$ in VBS-LNOX, 3.5, 3.0 and $4.1 \mu \mathrm{g} \mathrm{m}^{-3}$ in VBS-HNOX and 5.9, 1.4 and $3.1 \mu \mathrm{g} \mathrm{m}^{-3}$ in VBS-LA (Tables 1, 3). Thus, independent of the model configuration used, overestimations of plume OA occur on 2 days (16 and 29 July), while an underestimation appears on 21 July. The plume's $\mathrm{O}_{x}$ production for the 3 flight days, calculated again from the difference between the maximum concentrations and the background concentrations are, respectively, 12.9, 21.8 and $12.6 \mathrm{ppb}$ from the measurements, 18.3, 14.4 and $18.8 \mathrm{ppb}$ from VBS-LNOX, and 22.5, 13.9 and $19.7 \mathrm{ppb}$ from VBS-LA (Tables 1, 3). As for OA, we encounter an overestimation of plume $\mathrm{O}_{x}$ on 16 and 29 July, and an underestimation on 21 July. This suggests that the representation of photochemical conditions might be partially responsible for differences observed for OA and, thus, that 
Table 4. Correlation coefficients between OA and $\mathrm{O}_{x}$, SI-SOA and $\mathrm{O}_{x}$, ASOA and $\mathrm{O}_{x}$ and BSOA and $\mathrm{O}_{x}$ for the flights on 16, 21 and 29 July, both from the measurements (AMS) and simulations with VBS-LNOX, VBS-HNOX and VBS-LA.

\begin{tabular}{lccccc}
\hline Data & Date & $\mathrm{OA}^{\prime} \mathrm{O}_{x}$ & $\mathrm{SI}-\mathrm{SOA} / \mathrm{O}_{x}$ & $\mathrm{ASOA} / \mathrm{O}_{x}$ & $\mathrm{BSOA} / \mathrm{O}_{x}$ \\
\hline AMS & 16 Jul & 0.70 & & & \\
& 21 Jul & 0.71 & & & \\
& 29 Jul & 0.72 & & & \\
\hline VBS-LNOX & 16 Jul & 0.95 & 0.91 & 0.96 & 0.57 \\
& 21 Jul & 0.95 & 0.77 & 0.85 & 0.90 \\
& 29 Jul & 0.98 & 0.79 & 0.93 & 0.84 \\
\hline VBS-HNOX & 16 Jul & 0.96 & 0.90 & 0.96 & 0.45 \\
& 21 Jul & 0.95 & 0.77 & 0.92 & 0.88 \\
& 29 Jul & 0.98 & 0.78 & 0.95 & 0.80 \\
\hline VBS-LA & 16 Jul & 0.87 & 0.88 & 0.89 & 0.89 \\
& 21 Jul & 0.67 & 0.83 & 0.68 & 0.65 \\
& 29 Jul & 0.88 & 0.86 & 0.88 & 0.94 \\
\hline
\end{tabular}

Table 5. Slopes of OA vs. $\mathrm{O}_{x}$, SI-SOA vs. $\mathrm{O}_{x}$, ASOA vs. $\mathrm{O}_{x}$ and BSOA vs. $\mathrm{O}_{x}$ for the flights on 16,21 and 29 July, both from the measurements (AMS) and simulations with VBS-LNOX, VBS-HNOX and VBS-LA.

\begin{tabular}{lccccc}
\hline Data & Date & $\mathrm{OA} / \mathrm{O}_{x}$ & $\mathrm{SI}^{-S O A} / \mathrm{O}_{x}$ & $\mathrm{ASOA} / \mathrm{O}_{x}$ & $\mathrm{BSOA} / \mathrm{O}_{x}$ \\
\hline AMS & 16 Jul & 0.13 & & & \\
& 21 Jul & 0.14 & & & \\
& 29 Jul & 0.15 & & & \\
\hline \multirow{2}{*}{ VBS-LNOX } & 16 Jul & 0.23 & 0.04 & 0.18 & 0.02 \\
& 21 Jul & 0.29 & 0.02 & 0.11 & 0.16 \\
& 29 Jul & 0.26 & 0.03 & 0.14 & 0.09 \\
\hline \multirow{2}{*}{ VBS-HNOX } & 16 Jul & 0.15 & 0.04 & 0.10 & 0.01 \\
& 21 Jul & 0.24 & 0.02 & 0.08 & 0.15 \\
& 29 Jul & 0.19 & 0.03 & 0.09 & 0.08 \\
\hline VBS-LA & 16 Jul & 0.19 & 0.15 & 0.01 & 0.02 \\
& 21 Jul & 0.07 & 0.03 & 0.00 & 0.03 \\
& 29 Jul & 0.11 & 0.07 & 0.01 & 0.03 \\
\hline
\end{tabular}

the given data set could not be used directly for evaluation of the OA scheme in the model.

To overcome these problems, we analyze here OA versus $\mathrm{O}_{x}$ plots. As explained in the introduction, the slopes of these plots can represent in-plume OA buildup, normalized with respect to the availability of VOC precursors and oxidant agents $\left(\mathrm{OH}, \mathrm{O}_{3}\right.$ and $\left.\mathrm{NO}_{3}\right)$. This holds under the ideal hypothesis of a constant mix of VOC, SVOC and IVOC precursors on one hand, and oxidant agents on the other hand, for the considered data points of a flight. As explained in Sect. 2, we did not plot OOA or SOA vs. $\mathrm{O}_{x}$ because of the uncertainties related to PMF analysis and the definition of HOA comparing to POA or/and SI-SOA and cooking-related OA. In Sect. 2 we also presented correlations of about $0.7(R)$ between OA and $\mathrm{O}_{x}$ measured on the flight legs for a given day. Modeled $\mathrm{OA}$ and $\mathrm{O}_{x}$ on these flight legs show an even higher correlation of about 0.87 from VBS-LA, except for 0.67 on 21 July, and of more than 0.95 from VBS-HNOX and VBS-LNOX (Table 4). These good correlations suggest that we are close enough to the "constant mix" hypothesis to make the OA vs. $\mathrm{O}_{x}$ slope a useful metric. The simulated slopes of $\mathrm{OA} / \mathrm{O}_{x}$ are $0.23,0.29$ and $0.26 \mu \mathrm{g} \mathrm{m}^{-3} \mathrm{ppb}^{-1}$ with the VBS-LNOX configuration for the three flights on 16, 21 and 29 July, respectively (Fig. 6, Table 5). They overestimate the measured slopes of $0.13,0.14$ and $0.15 \mu \mathrm{g} \mathrm{m}^{-3} \mathrm{ppb}^{-1}$ by a factor between 1.7 and 2 . We noticed that the small variability in the relative differences between flights are due to the normalizing method (i.e., plotting OA vs. $\mathrm{O}_{x}$ to normalize with respect to photochemical conditions). This overestimation can be related to the SOA formation scheme: it is likely that the high-SOA yields under low- $\mathrm{NO}_{x}$ conditions are incorrect under plume conditions. The corresponding slopes in the VBSHNOX simulation with lower yields under high- $\mathrm{NO}_{x}$ conditions are $0.15,0.24$ and $0.19 \mu \mathrm{g} \mathrm{m}^{-3} \mathrm{ppb}^{-1}$, respectively. 
These slopes show a much lower overestimation with factors of $1.1,1.7$ and 1.3 for the 3 days. As for VBS-LA, the simulated $\mathrm{OA} / \mathrm{O}_{x}$ slope is overestimated by $46 \%$ on 16 July with up to $70 \%$ of the contribution of SI-SOA to the total OA, while it is underestimated by 50 and $27 \%$ on 21 and 29 July, respectively (Table 5). Thus, for all three flights, simulated $\mathrm{OA} / \mathrm{O}_{x}$ slopes with both VBS-HNOX and VBS-LA show a similar range of errors with respect to the observed slopes (even if the sign of errors is different). However, as we will show in Sect. 5, these two simulations show a very different distribution of ASOA, BSOA and SI-SOA buildup in the plume (Figs. S4-S6). Apparently, observed OA/O $\mathrm{O}_{x}$ slopes cannot constrain these distributions.

The measured slopes of OA vs. $\mathrm{O}_{x}$ during the first two flight legs on these days are close to the ones during the last two flight legs (Figs. S7, S8). This analysis focuses on the VBS-HNOX scheme. The modeled slopes of OA vs. $\mathrm{O}_{x}$ $\left(0.12,0.23\right.$ and $0.17 \mu \mathrm{g} \mathrm{m}^{-3} \mathrm{ppb}^{-1}$ for the 3 flights) are close to the measured ones $\left(0.12,0.18\right.$ and $\left.0.16 \mu \mathrm{g} \mathrm{m}^{-3} \mathrm{ppb}^{-1}\right)$ during the first two flight legs. Conversely, these slopes $(0.17$, 0.25 and $0.21 \mu \mathrm{g} \mathrm{m}^{-3} \mathrm{ppb}^{-1}$ ) are overestimated by factors of $1.3,1.9$, and 1.3 with respect to the measured ones during the last two flight legs. Thus, the overestimation of slopes occurs especially during the last two flight legs, which is related to relatively higher anthropogenic SOA formation due to continuous chemical aging when flights are farther away from fresh Paris emissions. The higher slopes during the last two flight legs than during the first two flight legs are not seen for BSOA, probably because the biogenic VOC emissions are more diffuse (Figs. S7, S8). Even if some differences are made evident, the good agreement of OA vs. $\mathrm{O}_{x}$ slopes between simulations and measurements represents a valuable validation of the VBS-HNOX scheme for the conditions of the Paris plume.

\section{Impact of the Paris plume on surrounding regions}

In this section we analyze the contribution of OA buildup from emissions in or near the Paris agglomeration to regional OA levels. This analysis is based on simulations with the VBS-HNOX configuration and the VBS-LA simulations, which show similar errors with respect to observed $\mathrm{OA} / \mathrm{O}_{x}$ slopes indicative for plume OA buildup. The VBS-LNOX simulation clearly showed larger errors. We will first analyze the individual buildup of OA species for the 3 flight days (Sect. 5.1), then we will study the time evolution of a pollution plume on 16 July (Sect. 5.2) and, finally, we will present the averaged results for July 2009.

\subsection{Plume buildup of individual OA species}

\subsubsection{VBS-HNOX simulation}

The slopes of modeled SI-SOA, ASOA (anthropogenic SOA) and BSOA (biogenic SOA) versus $\mathrm{O}_{x}$ are well correlated, generally with $R>0.7$ (Table 4, Fig. 6). The slopes are used here to analyze the plume production of individual OA species. SI-SOA is formed by functionalization and condensation of evaporated POA and IVOC species (Robinson et al., 2007) which are thought to be constituted by long alkane chains. SI-SOA vs. $\mathrm{O}_{x}$ slopes are 0.04, 0.02, and $0.03 \mu \mathrm{g} \mathrm{m}^{-3} \mathrm{ppb}^{-1}$ for the three flights, respectively (Table 5). They represent 27,8 , and $16 \%$ of the total OA vs. $\mathrm{O}_{x}$ slopes. Thus, SI-SOA has only a minor contribution to the Paris plume OA formation in this simulation. The anthropogenic photochemical production of ASOA from aromatics dominates the OA production on 16 and 29 July, with slopes of 0.10 and $0.09 \mu \mathrm{g} \mathrm{m}^{-3} \mathrm{ppb}^{-1}$, respectively, and of $0.08 \mu \mathrm{g} \mathrm{m}^{-3} \mathrm{ppb}^{-1}$ on 21 July (Table 5). On 29 and especially on 16 July, the SOA production is strongly influenced by anthropogenic emissions (by more than $90 \%$ ). A major contribution of anthropogenic VOC emissions to OA buildup in the Paris plume during MEGAPOLI flights has also been found by Freney et al. (2014), from a conjoint analysis by AMS OA measurements and PTR-MS (proton transfer reaction - mass spectrometry) VOC compounds. These results imply important SOA formation from the Paris agglomeration VOCs and to a lesser extent POA/SI-VOC emissions. Borbon et al. (2013) found emission ratios for C7-C9 aromatics in Paris which were by a factor of 2-3 higher than in Los Angeles and other French and European Union urban areas. This clearly could favor large anthropogenic SOA formation of OA in the Paris plume. Conversely, BSOA formation dominates the SOA production on 21 July, with a slope of BSOA vs. $\mathrm{O}_{x}$ of $0.15 \mu \mathrm{g} \mathrm{m}^{-3} \mathrm{ppb}^{-1}$ (Table 5), about $63 \%$ of the slope of OA vs. $\mathrm{O}_{x}$. BSOA formation can be due to both fresh BVOC (biogenic VOC) emissions from mainly isoprene emitting forests north of Paris and from condensation of biogenic SVOC when temperatures decrease in the later afternoon. Recently, the comparison of different VBSbased SOA schemes to chamber measurements in Zhao et al. (2015) suggests lower SOA formation from traditional VOC precursors (ASOA), by explicitly simulating the firstgeneration products, than when using the parametrization from Lane et al. (2008a) as in our study. In addition, Lane et al. (2008a) do not account for BSOA chemical aging, while we do based on the results of Zhang et al. (2013). Thus, the relative contributions of ASOA and BSOA to plume SOA buildup in the VBS-LNOX and VBS-HNOX configurations used in this paper are considered as an upper limit, while the primary SI-VOC emissions for SI-SOA formation are considered as a lower limit. Others studies taking into account fragmentation reactions (Jimenez et al., 2009; Shrivastava et al., 2011; Murphy et al., 2012) reduce OA formation.

\subsubsection{VBS-LA simulation}

In the alternative VBS-LA simulation, the contribution of SI-SOA to the total slopes is dominant, except on 21 July (Table 5; Fig. 6). SI-SOA vs. $\mathrm{O}_{x}$ slopes are $0.15,0.03$, and 


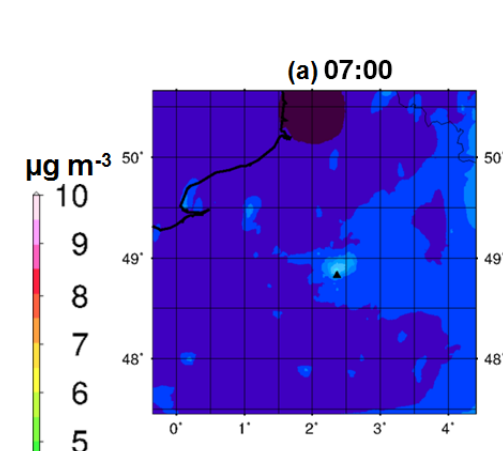

(d) $16: 00$

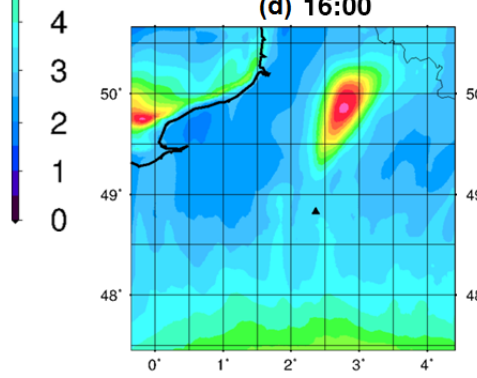

OA

(b) 10:00

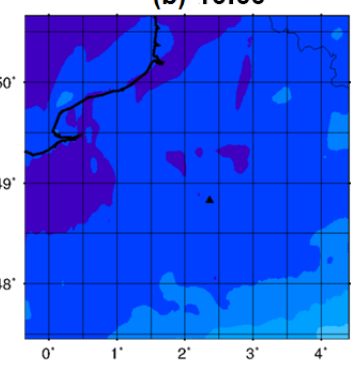

(e) $19: 00$

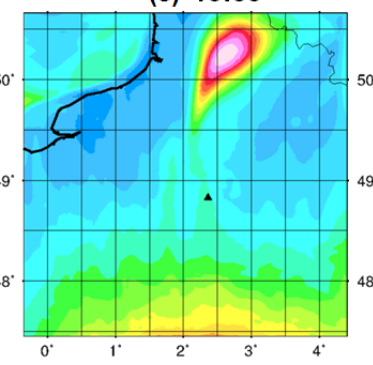

(c) 13:00

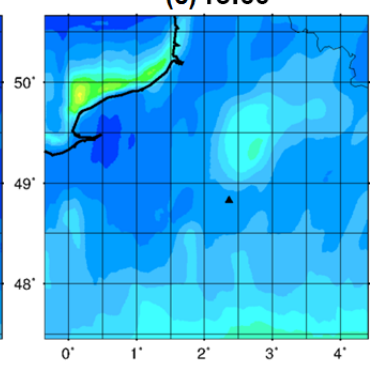

(f) $22: 00$

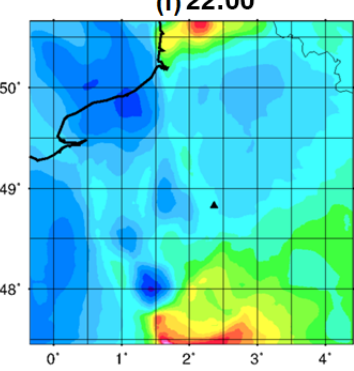

Figure 7. Urban OA $\left(\mathrm{PM}_{10}\right.$ fraction) plume $\left(\mu \mathrm{g} \mathrm{m}^{-3}\right)$ evolution on 16 July from VBS-HNOX, the triangle represents the location of Paris, illustrated by six panels (from a to f) corresponding to 07:00-22:00 (UTC + 2) with a time step of $3 \mathrm{~h}$.

$0.07 \mu \mathrm{g} \mathrm{m}^{-3} \mathrm{ppb}^{-1}$ for the three flights, respectively, and represent 79,42 , and $64 \%$ of the total OA vs. $\mathrm{O}_{x}$ slopes. ASOA vs. $\mathrm{O}_{x}$ slopes are negligible $\left(0.00\right.$ or $\left.0.01 \mu \mathrm{g} \mathrm{m}^{-3} \mathrm{ppb}^{-1}\right)$. BSOA vs. $\mathrm{O}_{x}$ slopes are $0.02,0.03$, and $0.03 \mu \mathrm{g} \mathrm{m}^{-3} \mathrm{ppb}^{-1}$ for the three flights, respectively, and represent 10, 42, and $27 \%$ of the total OA vs. $\mathrm{O}_{x}$ slopes. However, we noticed that for the VBS-LA simulation the uncertainty in the determination of the slope is larger than for VBS-HNOX. For all three SI-SOA vs. $\mathrm{O}_{x}$ plots, two regimes with two different slopes are observed. If the slope was only taken for points with larger SI-SOA and $\mathrm{O}_{x}$ values, which are closer to the plume, a larger slope would have been determined. To a lesser extent, this feature also appears for VBS-LNOX simulations.

The larger SI-SOA vs. $\mathrm{O}_{x}$ slopes in the VBS-LA simulation are easily explained by the larger POA emissions in this configuration. The range of SI-SOA vs. $\mathrm{O}_{x}$ slopes between the VBS-HNOX and the VBS-LA configuration represents the uncertainty due to POA emissions (Table 5). Even larger SI-SOA vs. $\mathrm{O}_{x}$ slopes during these flights would also be expected if the more aggressive SI-SOA formation scheme by Grieshop et al. (2009) had been used. With the Grieshop et al. (2009) formulation, SVOC species have a reaction rate constant 2 times lower than in this study with Robinson et al. (2007) but are shifted to 2 orders of magnitude lower volatility (instead of one), with a mass increase by $40 \%$ for each oxidation step (instead of $7.5 \%$ ). Box simulations by Dzepina et al. (2011) for Mexico City and by Hayes et al. (2015) for Los Angeles yield about 2 times larger SI-SOA yields with the Grieshop et al. (2009) scheme than with the Robinson et al. (2007) scheme. These results suggest an addi- tional possibility to increase SI-SOA contributions to plume SOA.

As a result of these comparisons, we come to the conclusion that, due to uncertainty both in POA emissions and in the SOA formation formulations, the constraint of observed OA vs. $\mathrm{O}_{x}$ slopes on the SOA distribution in the Paris plume is unfortunately weak. ASOA and SI-SOA could be the major anthropogenic SOA products for two flights, with varying contributions of BSOA.

\subsection{Time evolution of the plume on 16 July}

Figure 7 gives a typical picture of the OA species evolution in the Paris plume (at surface), simulated with both the VBSHNOX scheme and the VBS-LA scheme.

With the VBS-HNOX scheme, on 16 July at 07:00 UTC, a morning peak of OA is formed inside the Paris agglomeration as a result of POA emissions, low wind speeds, and a low boundary layer height. This peak of OA is then transported northeast. It disappears in the later morning (10:00 UTC) due to an increase of the PBL (planetary boundary layer) height and stronger winds. In the early afternoon (13:00 UTC), an OA plume is formed at about $50 \mathrm{~km}$ from the agglomeration center due to photochemical SOA production. At 16:00 UTC, the plume travels further northeast. The largest $\mathrm{OA}$ values occur between 49.5 and $50^{\circ} \mathrm{N}$, about $100 \mathrm{~km}$ north of Paris, in agreement with measurements. Major contributors, ASOA and SI-SOA, add more than 5 and $2 \mu \mathrm{g} \mathrm{m}^{-3}$ of OA to the plume maximum (Fig. 8). The ASOA and SI-SOA plumes are clearly separated from the Paris agglomeration, because 

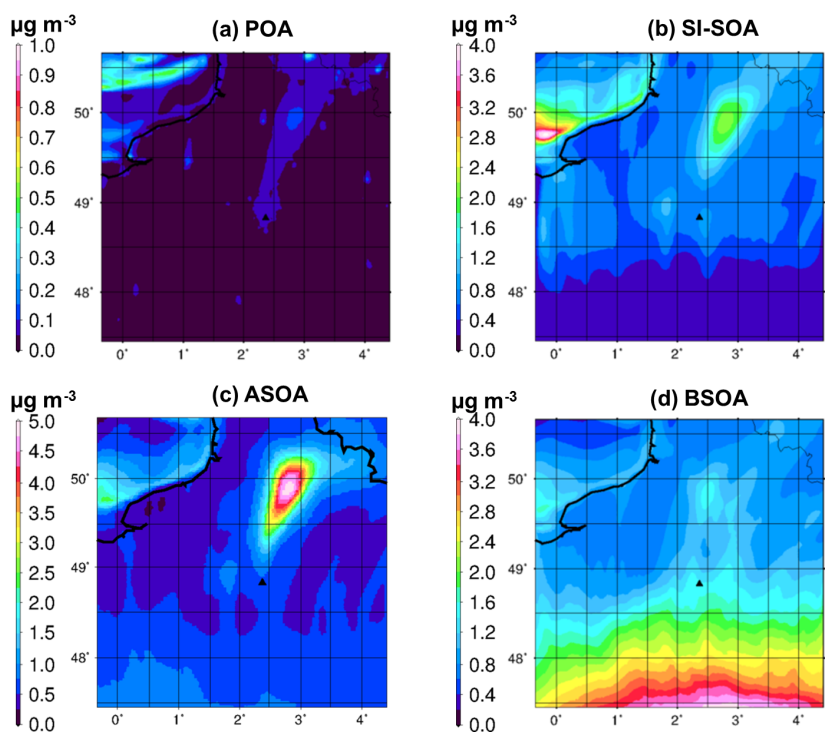

(d) BSOA

Figure 8. Urban POA (a), SI-SOA (b), ASOA (c) and BSOA (d) (in $\mathrm{PM}_{10}$ ) plumes $\left(\mu \mathrm{g} \mathrm{m}^{-3}\right)$ from VBS-HNOX at 16:00 $(\mathrm{UTC}+2)$ on 16 July; the triangle represents the location of Paris.

of (i) the time needed for processing of precursor emissions and (ii) the largest accumulation of precursor emissions in the early morning hours when wind speeds over the agglomeration are very low (also seen in the POA peak at the same location). BSOA contributes to the regional background and is little affected by the anthropogenic Paris agglomeration emissions (Fig. 8). The highest OA concentrations of about $10 \mu \mathrm{g} \mathrm{m}^{-3}$ occur in the evening at 19:00 UTC in northern France (at $\sim 150 \mathrm{~km}$ from the agglomeration center) due to continuous photochemical SVOC production and aging, and due to lower temperatures. At 22:00 UTC, the plume is leaving the MEG3 model domain.

This phenomenon of continuing SOA formation which is detached from the original rush hour emission area due to transport is very similar to that observed for Los Angeles in the CalNex study (Hayes et al., 2013).

The corresponding results obtained with the VBS-LA scheme are shown in the Supplement (Fig. S9). Morning OA concentrations are about 3 times larger than in VBSHNOX due to larger emissions, while the background concentrations are all lower than $1 \mu \mathrm{g} \mathrm{m}^{-3}$. At 13:00 UTC, an OA plume with a concentration about $6 \mu \mathrm{g} \mathrm{m}^{-3}$ higher than in VBS-HNOX is formed at about $50 \mathrm{~km}$ from the agglomeration center. While ASOA is the major contributor to OA plume formation in VBS-HNOX, SI-SOA formation contributes the most to the plume in VBS-LA and produces the maximum concentration of about $6 \mu \mathrm{g} \mathrm{m}^{-3}$ in the later afternoon at 16:00 UTC towards northern France. POA, ASOA and/or BSOA contribute less than $1 \mu \mathrm{g} \mathrm{m}^{-3}$ to the OA plume maximum (Fig. S10).

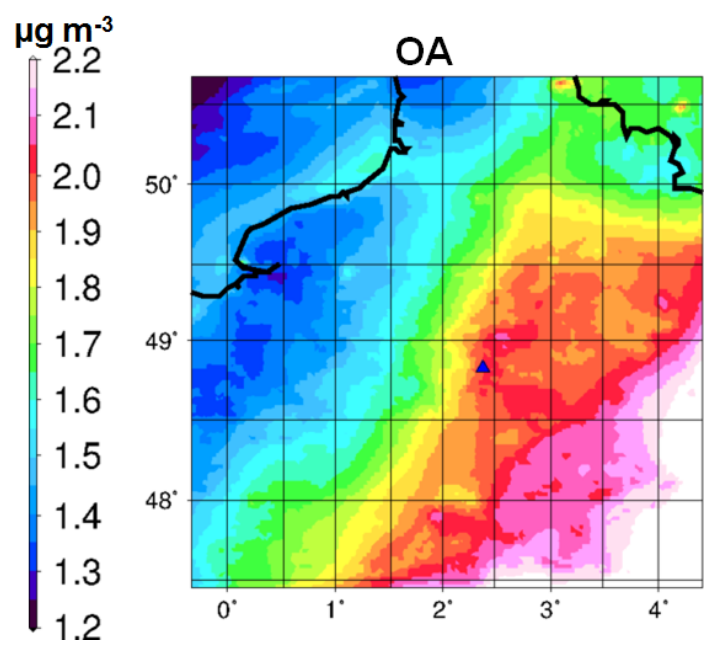

Figure 9. Modeled monthly mean OA concentration in $\mathrm{PM}_{10}$ $\left(\mu \mathrm{g} \mathrm{m}^{-3}\right)$ from VBS-HNOX; the triangle represents the location of Paris.
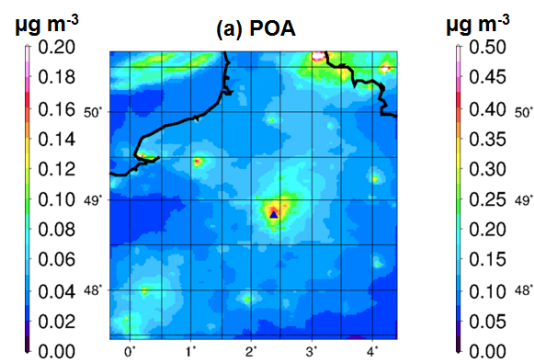

(b) SI-SOA

$\mu \mathbf{g ~ m}^{-3}$
$\mathbb{\pi} 0.50$
0.45
0.40
0.35
0.30
0.25
0.20
0.15
0.10
0.05
0.00 (c) ASOA

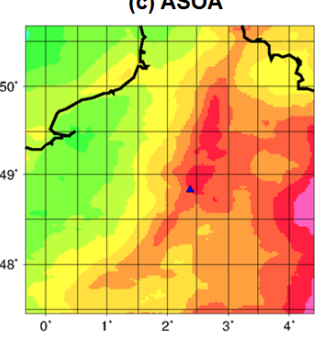

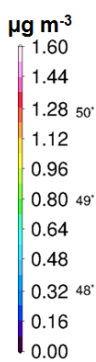

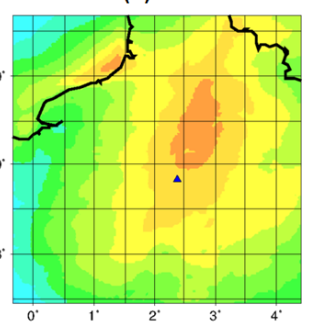

(d) BSOA

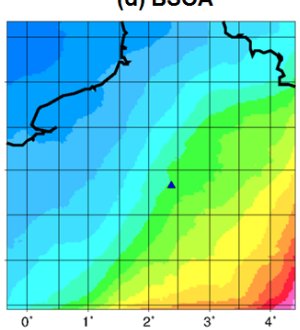

Figure 10. Modeled monthly mean POA (a), SI-SOA (b), ASOA (c) and BSOA (d) concentration in $\mathrm{PM}_{10}\left(\mu \mathrm{g} \mathrm{m}^{-3}\right)$ from VBS-HNOX; the triangle represents the location of Paris.

\subsection{Average July 2009 urban OA contribution to the surroundings of Paris}

Here, we analyze the regional-scale OA buildup from the Paris emissions for the average of July 2009 from the VBSHNOX (Figs. 9, 10) and VBS-LA simulations (Figs. S11, S12). For VBS-HNOX, average OA concentrations around the Paris agglomeration do not show distinctive pollution plumes but instead a strong W-E gradient near the agglomeration, presumably due to averaging different plume directions and due to differences in background conditions. OA values also show strong decreasing gradients at about 100 
$150 \mathrm{~km}$ in the N-NE of Paris. Contrary to VBS-HNOX, OA values from VBS-LA show a distinct OA plume from the Paris agglomeration: the absolute plume concentrations are lower. This behavior can be analyzed by considering specifically the contributions to OA.

For the VBS-HNOX simulation, the average POA from Paris emissions is only about $0.15 \mu \mathrm{g} \mathrm{m}^{-3}$ over Paris and the area of enhanced values extends to the E-NE because of the largest climatological frequency of southwesterly to westerly winds in July (Fig. 10). The areas of enhancements of POA occur on a length scale of some tens of kilometers around the agglomeration. ASOA is enhanced within the agglomeration and within the SW and NNE plume, up to $100-150 \mathrm{~km}$ downwind of the agglomeration, respectively. The maximum concentrations in these plumes are 0.4 and $0.35 \mu \mathrm{g} \mathrm{m}^{-3}$, respectively (always for the July 2009 average). In the NNE direction, enhanced values originate from pollution events under SW flow, such as those studied in this work (see Sect. 5.2). The enhanced values in the SW originate from a pronounced pollution plume occurring in the beginning of July, for which no measurements were available. SI-SOA is most enhanced in the NNE direction, where its maximum concentration is about $0.35 \mu \mathrm{g} \mathrm{m}^{-3}$, thus somewhat smaller than the ASOA concentration. It is worth noting that these increases in ASOA and SI-SOA concentrations are much larger when analyzing individual events than when looking at averages, due to different plume angles on different days and thus diluting the average fields. The BSOA component does not show distinct plumes, but a continuous $\mathrm{NW} / \mathrm{W}-\mathrm{SE} / \mathrm{E}$ gradient that is the continental character of air masses implies large average BSOA concentrations. BSOA is the strongest contributor to OA over the domain. Its gradient is responsible for the W-E OA gradient noticed earlier, with smaller contributions from the other components.

For the VBS-LA simulation, the larger primary S/IVOC emissions within the LA inventory lead to a larger average POA concentration of up to $0.7 \mu \mathrm{g} \mathrm{m}^{-3}$ within the Paris agglomeration. The monthly maximum plume SI-SOA concentration is about $0.3 \mu \mathrm{g} \mathrm{m}^{-3}$ in VBS-LA (Fig. S12). The lower SI-SOA concentration albeit with higher POA concentrations is due to lower OA load in the plume. Indeed, the monthly average plume ASOA concentration is small, below $0.05 \mu \mathrm{g} \mathrm{m}^{-3}$, and the plume BSOA concentration is below $0.3 \mu \mathrm{g} \mathrm{m}^{-3}$. BSOA shows a similar spatial pattern in VBSLA but with lower absolute values than in VBS-HNOX.

In conclusion, both the VBS-HNOX and VBS-LA simulations show different monthly average OA product distributions. As discussed above, the ASOA and BSOA contributions in VBS-HNOX represent an upper limit for ASOA and BSOA produced in the plume (and in background air masses). Conversely, the small plume and background values in VBS-LA simulated without any chemical aging are probably underestimated, in particular because they underestimate the SOA observations within the Paris agglomeration (Zhang et al., 2013). Moreover, for SI-SOA, the differ- ences between both simulations are weak. However, alternative VBS schemes (Grieshop et al., 2009) would simulate a higher SI-SOA formation, as noted above (about a factor 2 from box model studies in other urban plumes).

\section{Conclusion}

CHIMERE simulations are used to study the secondary pollutant formation in the Paris plume and its impact on the surrounding regions. This study focusses on 3 photochemically active days for which airborne observations are available. Three simulation configurations are set up in order to cover the range of uncertainty in emissions and in different formulations of the SOA buildup in the frame of the VBS scheme. Primary pollutants within the plume, such as $\mathrm{NO}_{x}, \mathrm{BC}$ and probably also POA, are clearly underestimated in the model when using the MEGAPOLI inventory, and to a lesser extent with the EMEP-LA inventory. For two of the three flights, this underestimation is probably due to too high wind speeds in the morning over the Paris agglomeration, not allowing for strong enough pollution accumulation. Conversely, ozone is slightly overestimated in the plume and in background air masses, as is $\mathrm{O}_{x}$. This is not contradictory since the chemical regime in Paris and its surroundings is generally $\mathrm{NO}_{x}$ saturated (Deguillaume et al., 2008). Both in observations and simulations, predicted (and measured) OA is very well correlated with predicted (and measured) $\mathrm{O}_{x}$. The ratio of the photochemical productivities of SOA and $\mathrm{O}_{x}$ (represented by the slope of OA vs. $\mathrm{O}_{x}$ ) is well simulated (overestimation of less than $30 \%$ on the average of 3 days) for the Paris plume from VBS-HNOX when low SOA yields are applied on the SOA formation scheme. The overestimation might be related to too large yields of ASOA in the VBS scheme set up in this work, which was based on the parameters given in Lane et al. (2008a) and Murphy and Pandis (2009). Nevertheless, this good agreement is an important result in evaluating the VBS scheme with field data. Combined with similar recent results for the Tokyo megacity (Morino et al., 2014), it shows good performance of the VBS schemes in large urban areas and in their plumes. When considering the OA to $\mathrm{O}_{x}$ slopes, the day to day variability in model to observation results is much lower than for OA alone. Observed OA vs. $\mathrm{O}_{x}$ slopes of about $0.14-0.15 \mu \mathrm{g} \mathrm{m}^{-3} \mathrm{ppb}^{-1}$ compare well to those observed in the Mexico City, Los Angeles and Tokyo plumes with different emissions and photochemical conditions during different seasons (Fig. 1).

However, an alternative scheme with 3 times larger POA emissions, and without ASOA and BSOA aging, also shows good agreement with observed OA vs. $\mathrm{O}_{x}$ slopes, though it strongly underestimates background and urban Paris OA. This leads us to the conclusion that due to uncertainties both in POA emissions and in the SOA formation formulations, uncertainly in the SOA product distribution remains large. The constraint of observed OA vs. $\mathrm{O}_{x}$ slopes on the SOA 
product distribution in the Paris plume is unfortunately weak and does not reduce this uncertainty (while it does for anthropogenic OA yields). Both ASOA and SI-SOA could be the major anthropogenic SOA products for two of the flights. In the simulations, anthropogenic SOA is the major contributor to plume SOA on two flight days, while BSOA is the major or equal contributor on the third day.

Predicted maximum OA is found on the flight leg most distant from the agglomeration (at about $150 \mathrm{~km}$ ), as for observations, indicating secondary anthropogenic SOA formation from Paris emissions over all the distances and during several hours. On a monthly average, OA from Paris emissions contributes to the OA regional buildup at different length scales, from several tens of kilometers for POA to several hundreds of kilometers for ASOA and SI-SOA. Clearly, a combination of ASOA and SI-SOA buildup from precursor emissions in the Paris agglomeration affects atmospheric composition at a regional scale. Simulating this buildup has been possible only after an original model evaluation showing good agreement between simulated and observed OA to $\mathrm{O}_{x}$ slopes. This slope is an interesting parameter to measure the SOA buildup efficiency of a given environment.

\section{The Supplement related to this article is available online at doi:10.5194/acp-15-13973-2015-supplement.}

Acknowledgements. The research leading to these results has received funding from the European Community's Seventh Framework Programme FP/2007-2011 under grant agreement no. 212520. Support from the French ANR project MEGAPOLI - PARIS (ANR-09-BLAN-0356), from the CNRS-INSU/FEFE via l'ADEME (no. 0962c0018) and the Ile de France/SEPPE are acknowledged. We would like to thank the pilots, the flight crew, and the whole SAFIRE team for operating the ATR-42 aircraft. A part of the work was supported by a PhD grant from CIFRE (ANRT) to Q. J. Zhang (at LISA/CNRS and ARIA Technologies).

Edited by: J.-L. Jimenez

\section{References}

Aumont, B., Valorso, R., Mouchel-Vallon, C., Camredon, M., LeeTaylor, J., and Madronich, S.: Modeling SOA formation from the oxidation of intermediate volatility n-alkanes, Atmos. Chem. Phys., 12, 7577-7589, doi:10.5194/acp-12-7577-2012, 2012.

Beekmann, M. and Vautard, R.: A modelling study of photochemical regimes over Europe: robustness and variability, Atmos. Chem. Phys., 10, 10067-10084, doi:10.5194/acp-1010067-2010, 2010.

Beekmann, M., Prévôt, A. S. H., Drewnick, F., Sciare, J., Pandis, S. N., Denier van der Gon, H. A. C., Crippa, M., Freutel, F., Poulain, L., Ghersi, V., Rodriguez, E., Beirle, S., Zotter, P., von der
Weiden-Reinmü ller, S.-L., Bressi, M., Fountoukis, C., Petetin, H., Szidat, S., Schneider, J., Rosso, A., El Haddad, I., Megaritis, A., Zhang, Q. J., Michoud, V., Slowik, J. G., Moukhtar, S., Kolmonen, P., Stohl, A., Eckhardt, S., Borbon, A., Gros, V., Marchand, N., Jaffrezo, J. L., Schwarzenboeck, A., Colomb, A., Wiedensohler, A., Borrmann, S., Lawrence, M., Baklanov, A., and Baltensperger, U.: In situ, satellite measurement and model evidence on the dominant regional contribution to fine particulate matter levels in the Paris megacity, Atmos. Chem. Phys., 15, 9577-9591, doi:10.5194/acp-15-9577-2015, 2015.

Bessagnet, B., Menut, L., Curci, G., Hodzic, A., Guillaume, B., Liousse, C., Moukhtar, S., Pun, B., Seigneur, C., and Schulz, M.: Regional modeling of carbonaceous aerosols over Europe - focus on secondary organic aerosols, J. Atmos. Chem., 61, 175-202, 2009.

Borbon, A., Gilman, J. B., Kuster, W. C., Grand, N., Chevaillier, S., Colomb, A., Dolgorouky, C., Gros, V., Lopez, M., Sarda-Esteve, R., Holloway, J., Stutz, J., Perrussel, O., Petetin, H., McKeen, S., Beekmann, M., Warneke, C., Parrish, D. D., and de Gouw, J. A.: Emission ratios of anthropogenic VOC in northern mid-latitude megacities: observations vs. emission inventories in Los Angeles and Paris, J. Geophys. Res., 118, 2041-2057, 2013.

Cappa, C. D. and Wilson, K. R.: Multi-generation gas-phase oxidation, equilibrium partitioning, and the formation and evolution of secondary organic aerosol, Atmos. Chem. Phys., 12, 9505-9528, doi:10.5194/acp-12-9505-2012, 2012.

Crippa, M., DeCarlo, P. F., Slowik, J. G., Mohr, C., Heringa, M. F., Chirico, R., Poulain, L., Freutel, F., Sciare, J., Cozic, J., Di Marco, C. F., Elsasser, M., Nicolas, J. B., Marchand, N., Abidi, E., Wiedensohler, A., Drewnick, F., Schneider, J., Borrmann, S., Nemitz, E., Zimmermann, R., Jaffrezo, J.-L., Prévôt, A. S. H., and Baltensperger, U.: Wintertime aerosol chemical composition and source apportionment of the organic fraction in the metropolitan area of Paris, Atmos. Chem. Phys., 13, 961-981, doi:10.5194/acp-13-961-2013, 2013.

Deguillaume, L., Beekmann, M., and Derognat, C.: Uncertainty evaluation of ozone production and its sensitivity to emission changes over the Ile-de-France region during summer periods, J. Geophys. Res., 113, D02304, doi:10.1029/2007JD009081, 2008.

Derognat, C., Beekmann, M., Baeumle, M., Martin, D., and Schmidt, H.: Effect of biogenic volatile organic compound emissions on tropospheric chemistry during the atmospheric Pollution Over the Paris Area (ESQUIF) campaign in the Ile-de-France region, J. Geophys. Res., 108, 8560, doi:10.1029/2001JD001421, 2003.

Donahue, N. M., Robinson, A. L., Stanier, C. O., and Pandis, S. N.: Coupled partitioning, dilution, and chemical aging of semivolatile organics, Environ. Sci. Technol., 40, 2635-2643, 2006.

Dudhia, J.: A nonhydrostatic version of the Penn State/NCAR mesoscale model: validation tests and simulation of an Atlantic cyclone and cold front, Mon. Weather Rev., 121, 1493-1513, 1993.

Dzepina, K., Cappa, C. D., Volkamer, R. M., Madronich, S., DeCarlo, P. F., Zaveri, R. A., and Jimenez, J. L.: Modeling the Multiday Evolution and Aging of Secondary Organic Aerosol During MILAGRO 2006, Environ. Sci. Technol., 45, 3496-3503, doi:10.1021/es103186f, 2011. 
Freney, E. J., Sellegri, K., Canonaco, F., Colomb, A., Borbon, A., Michoud, V., Doussin, J.-F., Crumeyrolle, S., Amarouche, N., Pichon, J.-M., Bourianne, T., Gomes, L., Prevot, A. S. H., Beekmann, M., and Schwarzenböeck, A.: Characterizing the impact of urban emissions on regional aerosol particles: airborne measurements during the MEGAPOLI experiment, Atmos. Chem. Phys., 14, 1397-1412, doi:10.5194/acp-14-1397-2014, 2014.

Freutel, F., Schneider, J., Drewnick, F., von der Weiden-Reinmüller, S.-L., Crippa, M., Prévôt, A. S. H., Baltensperger, U., Poulain, L., Wiedensohler, A., Sciare, J., Sarda-Estève, R., Burkhart, J. F., Eckhardt, S., Stohl, A., Gros, V., Colomb, A., Michoud, V., Doussin, J. F., Borbon, A., Haeffelin, M., Morille, Y., Beekmann, M., and Borrmann, S.: Aerosol particle measurements at three stationary sites in the megacity of Paris during summer 2009: meteorology and air mass origin dominate aerosol particle composition and size distribution, Atmos. Chem. Phys., 13, 933-959, doi:10.5194/acp-13-933-2013, 2013.

Grieshop, A. P., Logue, J. M., Donahue, N. M., and Robinson, A. L.: Laboratory investigation of photochemical oxidation of organic aerosol from wood fires 1: measurement and simulation of organic aerosol evolution, Atmos. Chem. Phys., 9, 1263-1277, doi:10.5194/acp-9-1263-2009, 2009.

Guenther, A., Karl, T., Harley, P., Wiedinmyer, C., Palmer, P. I., and Geron, C.: Estimates of global terrestrial isoprene emissions using MEGAN (Model of Emissions of Gases and Aerosols from Nature), Atmos. Chem. Phys., 6, 3181-3210, doi:10.5194/acp-63181-2006, 2006.

Gurjar, B. R., Jain, A., Sharma, A., Agarwal, A., Gupta, P., Nagpure, A. S., and Lelieveld, J.: Human health risksin megacities due to air pollution, Atmos. Environ., 44, 4606-4613, 2010.

Hallquist, M., Wenger, J. C., Baltensperger, U., Rudich, Y., Simpson, D., Claeys, M., Dommen, J., Donahue, N. M., George, C., Goldstein, A. H., Hamilton, J. F., Herrmann, H., Hoffmann, T., Iinuma, Y., Jang, M., Jenkin, M. E., Jimenez, J. L., Kiendler-Scharr, A., Maenhaut, W., McFiggans, G., Mentel, Th. F., Monod, A., Prévôt, A. S. H., Seinfeld, J. H., Surratt, J. D., Szmigielski, R., and Wildt, J.: The formation, properties and impact of secondary organic aerosol: current and emerging issues, Atmos. Chem. Phys., 9, 5155-5236, doi:10.5194/acp-9-51552009, 2009.

Hauglustaine, D. A., Hourdin, F., Jourdain, L., Filiberti, M. A., Walters, S., Lamarque, J.-F., and Holland, E. A.: Interactive chemistry in the Laboratoire de Meteorologie. Dynamique general circulation model: Description and background tropospheric chemistry evaluation, J. Geophys. Res., 109, D04314, doi:10.1029/2003JD003957, 2004.

Hayes, P. L., Ortega, A. M., Cubison, M. J., Froyd, K. D., Zhao, Y., Cliff, S. S., Hu, W. W., Toohey, D. W., Flynn, J. H., Lefer, B. L., Grossberg, N., Alvarez, S., Rappenglück, B., Taylor, J. W., Allan, J. D., Holloway, J. S., Gilman, J. B., Kuster, W. C., Gouw, J. A., Massoli, P., Zhang, X., Liu, J., Weber, R. J., Corrigan, A. L., Russell, L. M., Isaacman, G., Worton, D. R., Kreisberg, N. M., Goldstein, A. H., Thalman, R., Waxman, E. M., Volkamer, R., Lin, Y. H., Surratt, J. D., Kleindienst, T. E., Offenberg, J. H., Dusanter, S., Griffith, S., Stevens, P. S., Brioude, J., Angevine, W. M., and Jimenez, J. L.: Organic aerosol composition and sources in Pasadena, California during the 2010 CalNex campaign, J. Geophys. Res.-Atmos., 118, 9233-9257, doi:10.1002/jgrd.50530, 2013.
Hayes, P. L., Carlton, A. G., Baker, K. R., Ahmadov, R., Washenfelder, R. A., Alvarez, S., Rappenglück, B., Gilman, J. B., Kuster, W. C., de Gouw, J. A., Zotter, P., Prévôt, A. S. H., Szidat, S., Kleindienst, T. E., Offenberg, J. H., Ma, P. K., and Jimenez, J. L.: Modeling the formation and aging of secondary organic aerosols in Los Angeles during CalNex 2010, Atmos. Chem. Phys., 15, 5773-5801, doi:10.5194/acp-15-5773-2015, 2015.

Herndon, S., Onasch, T., Wood, E. C., Kroll, J. H., Canagaratna, M., Jayne, J., Zavala, M., Knighton, W. B., Mazzoleni, C., Dubey, M. K., Ulbrich, I., Jimenez, J. L., Seila, R., de Gouw, J. A., De Foy, B., Fast, J., Molina, L., Kolb, C. E., and Worsnop, D. R.: The correlation of secondary organic aerosol with odd oxygen in Mexico City, Geophys. Res. Lett., 35, L15804, oi:10.1029/2008GL034058, 2008.

Hodzic, A., Jimenez, J. L., Madronich, S., Canagaratna, M. R., DeCarlo, P. F., Kleinman, L., and Fast, J.: Modeling organic aerosols in a megacity: potential contribution of semi-volatile and intermediate volatility primary organic compounds to secondary organic aerosol formation, Atmos. Chem. Phys., 10, 5491-5514, doi:10.5194/acp-10-5491-2010, 2010.

Honoré, C., Rouil, L., Vautard, R., Beekmann, M., Bessagnet, B., Dufour, A., Elichegaray, C., Flaud, J.-M., Malherbe, L., Meleux, F., Menut, L., Martin, D., Peuch, A., Peuch, V. H., and Poisson, N.: Predictability of European air quality: The assessment of three years of operational forecasts and analyses by the PREV'AIR system, J. Geophys. Res., 113, D04301, doi:10.1029/2007JD008761, 2008.

IPCC: Climate Change 2013: The Physical Science Basis: Summary for Policymakers, Cambridge, UK, 2013.

Jimenez, J. L., Canagaratna, M. R., Donahue, N. M., Prevot, A. S. H., Zhang, Q., Kroll, J. H., DeCarlo, P. F., Allan, J. D., Coe, H., Ng, N. L., Aiken, A. C., Docherty, K. S., Ulbrich, I. M., Grieshop, A. P., Robinson, A. L., Duplissy, J., Smith, J. D., Wilson, K. R., Lanz, V. A., Hueglin, C., Sun, Y. L., Tian, J., Laaksonen, A., Raatikainen, T., Rautiainen, J., Vaattovaara, P., Ehn, M., Kulmala, M., Tomlinson, J. M., Collins, D. R., Cubison, M. J., Dunlea, E. J., Huffman, J. A., Onasch, T. B., Alfarra, M. R., Williams, P. I., Bower, K., Kondo, Y., Schneider, J., Drewnick, F., Borrmann, S., Weimer, S., Demerjian, K., Salcedo, D., Cottrell, L., Griffin, R., Takami, A., Miyoshi, T., Hatakeyama, S., Shimono, A., Sun, J. Y., Zhang, Y. M., Dzepina, K., Kimmel, J. R., Sueper, D., Jayne, J. T., Herndon, S. C., Trimborn, A. M., Williams, L. R., Wood, E. C., Middlebrook, A. M., Kolb, C. E., Baltensperger, U., and Worsnop, D. R.: Evolution of Organic Aerosols in the Atmosphere, Science, 326, 1525-1529, doi:10.1126/science.1180353, 2009.

Junker, C. and Liousse, C.: A global emission inventory of carbonaceous aerosol from historic records of fossil fuel and biofuel consumption for the period 1860-1997, Atmos. Chem. Phys., 8, 1195-1207, doi:10.5194/acp-8-1195-2008, 2008.

Kleinman, L. I., Daum, P. H., Lee, J. H., Lee, Y.-N., Nunnermacker, L. J., Springston, S. R., Newman, L., Weinstein-Lloyd, J., and Sillman, S.: Dependence of ozone production on NO and hydrocarbons in the troposphere, Geophys. Res. Lett., 24, 2299-2302, 1997.

Lane, T. E., Donahue, N. M., and Pandis, S. N.: Simulating secondary organic aerosol formation using the volatility basis-set approach in a chemical transport model, Atmos. Environ., 42, 7439-7451, 2008a. 
Lane, T. E., Donahue, N. M., and Pandis, S. N.: Effect of NOx on secondary organic aerosol concentrations, Environ. Sci. Technol., 42, 6022-6027, 2008b.

Lattuati, M.: Contribution à l'étude du bilan de l'ozone troposphérique à l'interface de l'Europe et de l'Atlantique Nord: modélisation lagrangienne et mesures en altitude. Thèse de sciences, Université Paris 6, France, 1997.

Menut, L., Bessagnet, B., Khvorostyanov, D., Beekmann, M., Blond, N., Colette, A., Coll, I., Curci, G., Foret, G., Hodzic, A., Mailler, S., Meleux, F., Monge, J.-L., Pison, I., Siour, G., Turquety, S., Valari, M., Vautard, R., and Vivanco, M. G.: CHIMERE 2013: a model for regional atmospheric composition modelling, Geosci. Model Dev., 6, 981-1028, doi:10.5194/gmd6-981-2013, 2013.

Molina, L. T., Madronich, S., Gaffney, J. S., Apel, E., de Foy, B., Fast, J., Ferrare, R., Herndon, S., Jimenez, J. L., Lamb, B., Osornio-Vargas, A. R., Russell, P., Schauer, J. J., Stevens, P. S., Volkamer, R., and Zavala, M.: An overview of the MILAGRO 2006 Campaign: Mexico City emissions and their transport and transformation, Atmos. Chem. Phys., 10, 8697-8760, doi:10.5194/acp-10-8697-2010, 2010.

Morino, Y., Tanabe, K., Sato, K., and Ohara, T.: Secondary organic aerosol model intercomparison based on secondary organic aerosol to odd oxygen ratio in Tokyo, J. Geophys. Res.-Atmos., 119, 13489-13505, doi:10.1002/2014JD021937, 2014.

Murphy, B. N. and Pandis, S. N.: Simulating the formation of semivolatile primary and secondary organic aerosol in a regional chemical transport model, Environ. Sci. Technol., 43, 47224728, 2009.

Murphy, B. N., Donahue, N. M., Fountoukis, C., Dall'Osto, M., O'Dowd, C., Kiendler-Scharr, A., and Pandis, S. N.: Functionalization and fragmentation during ambient organic aerosol aging: application of the 2-D volatility basis set to field studies, Atmos. Chem. Phys., 12, 10797-10816, doi:10.5194/acp-1210797-2012, 2012.

Nenes, A., Pilinis, C., and Pandis, S.: ISORROPIA: A new thermodynamic model for inorganic multicomponent atmospheric aerosols, Aquatic Geochem., 4, 123-152, 1998.

Petetin, H., Beekmann, M., Sciare, J., Bressi, M., Rosso, A., Sanchez, O., and Ghersi, V.: A novel model evaluation approach focusing on local and advected contributions to urban $\mathrm{PM}_{2.5}$ levels - application to Paris, France, Geosci. Model Dev., 7, 1483 1505, doi:10.5194/gmd-7-1483-2014, 2014.

Petetin, H., Beekmann, M., Colomb, A., Denier van der Gon, H. A. C., Dupont, J.-C., Honoré, C., Michoud, V., Morille, Y., Perrussel, O., Schwarzenboeck, A., Sciare, J., Wiedensohler, A., and Zhang, Q. J.: Evaluating $\mathrm{BC}$ and $\mathrm{NO}_{x}$ emission inventories for the Paris region from MEGAPOLI aircraft measurements, Atmos. Chem. Phys., 15, 9799-9818, doi:10.5194/acp-15-97992015, 2015.

Pun, B. K., Seigneur, C., and Lohman, K.: Modeling secondary organic aerosol formation via multiphase partitioning with molecular data, Environ. Sci. Technol., 40, 4722-4731, doi:10.1021/es0522736, 2006.

Robinson, A. L., Donahue, N. M., Shrivastava, M. K., Weitkamp, E. A., Sage, A. M., Grieshop, A. P., Lane, T. E., Pierce, J. R., and Pandis, S. N.: Rethinking organic aerosols: Semivolatile emissions and photochemical aging, Science, 315, 1259-1262, 2007.
Sciare, J., d'Argouges, O., Zhang, Q. J., Sarda-Estève, R., Gaimoz, C., Gros, V., Beekmann, M., and Sanchez, O.: Comparison between simulated and observed chemical composition of fine aerosols in Paris (France) during springtime: contribution of regional versus continental emissions, Atmos. Chem. Phys., 10, 11987-12004, doi:10.5194/acp-10-11987-2010, 2010.

Seinfeld, J. H. and Pandis, S. N.: Atmospheric Chemistry and Physics: From Air Pollution to Climate Changes, John Wiley, Hoboken, NJ, 2006.

Shaiganfar, R., Beirle, S., Petetin, H., Zhang, Q., Beekmann, M., and Wagner, T.: New concepts for the comparison of tropospheric $\mathrm{NO}_{2}$ column densities derived from car-MAX-DOAS observations, OMI satellite observations and the regional model CHIMERE during two MEGAPOLI campaigns in Paris 2009/10, Atmos. Meas. Tech., 8, 2827-2852, doi:10.5194/amt-8-28272015, 2015.

Shrivastava, M., Fast, J., Easter, R., Gustafson Jr., W. I., Zaveri, R. A., Jimenez, J. L., Saide, P., and Hodzic, A.: Modeling organic aerosols in a megacity: comparison of simple and complex representations of the volatility basis set approach, Atmos. Chem. Phys., 11, 6639-6662, doi:10.5194/acp-11-6639-2011, 2011.

Shrivastava, M., Zelenyuk, A., Imre, D., Easter, R. C., Beranek,, J., Zaveri, R. A., and Fast, J. D.: Implications of Low Volatility and Gas-phase Fragmentation Reactions on SOA Loadings and their Spatial and Temporal Evolution in the Atmosphere, J. Geophys Res.-Atmos., 118, 3328-3342, doi:10.1002/jgrd.50160, 2013.

Timmermans, R. M. A., Denier van der Gon, H. A. C., Kuenen, J. J. P., Segers, A. J., Honoré, C., Perrussel, O., Builtjes, P. J. H., and Schaap, M.: Quantification of the urban air pollution increment and its dependency on the use of down-scaled and bottom-up city emission inventories, Urban Climate, 6, 46-62, 2013.

United Nations (UN): World Urbanization Prospects, the $2011 \mathrm{Re}-$ vision, available at: esa.un.org/unpd/wup/index.htm (last access: 6 December 2015), 2014.

Valorso, R., Aumont, B., Camredon, M., Raventos-Duran, T., Mouchel-Vallon, C., Ng, N. L., Seinfeld, J. H., Lee-Taylor, J., and Madronich, S.: Explicit modelling of SOA formation from apinene photooxidation: sensitivity to vapour pressure estimation, Atmos. Chem. Phys., 11, 6895-6910, doi:10.5194/acp-11-68952011, 2011.

Vautard, R., Beekmann, M., Roux, J., and Gombert, D.: Validation of a hybrid forecasting system for the ozone concentrations over the Paris region, Atmos. Environ., 35, 2449-2461, 2001.

Wood, E. C., Canagaratna, M. R., Herndon, S. C., Onasch, T. B., Kolb, C. E., Worsnop, D. R., Kroll, J. H., Knighton, W. B., Seila, R., Zavala, M., Molina, L. T., DeCarlo, P. F., Jimenez, J. L., Weinheimer, A. J., Knapp, D. J., Jobson, B. T., Stutz, J., Kuster, W. C., and Williams, E. J.: Investigation of the correlation between odd oxygen and secondary organic aerosol in Mexico City and Houston, Atmos. Chem. Phys., 10, 8947-8968, doi:10.5194/acp-10-8947-2010, 2010.

Zhang, Q. J., Laurent, B., Velay-Lasry, F., Ngo, R., Derognat, C., Marticorena, B., and Albergel, A.: An Air Quality Forecasting System in Beijing - Application to the Study of Dust Storm Events in China in May 2008, J. Environ. Sci., 24, 102-111, doi:10.1016/S1001-0742(11)60733-X, 2012.

Zhang, Q. J., Beekmann, M., Drewnick, F., Freutel, F., Schneider, J., Crippa, M., Prevot, A. S. H., Baltensperger, U., Poulain, L., Wiedensohler, A., Sciare, J., Gros, V., Borbon, A., Colomb, A., 
Michoud, V., Doussin, J.-F., Denier van der Gon, H. A. C., Haeffelin, M., Dupont, J.-C., Siour, G., Petetin, H., Bessagnet, B., Pandis, S. N., Hodzic, A., Sanchez, O., Honoré, C., and Perrussel, O.: Formation of organic aerosol in the Paris region during the MEGAPOLI summer campaign: evaluation of the volatilitybasis-set approach within the CHIMERE model, Atmos. Chem. Phys., 13, 5767-5790, doi:10.5194/acp-13-5767-2013, 2013.
Zhao, B., Wang, S., Donahue, N. M., Chuang, W., Hildebrandt Ruiz, L., Ng, N. L., Wang, Y., and Hao, J.: Evaluation of OneDimensional and Two-Dimensional Volatility Basis Sets in Simulating the Aging of Secondary Organic Aerosol with SmogChamber Experiments, Environ. Sci. Technol., 49, 2245-2254, 2015. 